\title{
GREY-WPCA BASED PARAMETRIC-OPTIMIZATION AND MODELLING OF CHROMIUM POWDER MIXED SURFACE- ELECTRO DISCHARGE DIAMOND GRINDING OF INCONEL 600 USING RSM
}

\author{
MANOJ Modi' ${ }^{1}$, GOPAL Agarwal ${ }^{2}$, SWATI D Chaugaonkar ${ }^{3}$ \\ ${ }^{1}$ Acropolis Institute of Technology and Research, Department of Mechanical Engineering, \\ Indore, India, e - mail: manojmnitjaipurl @ gmail.com \\ ${ }^{2}$ Malaviya National Institute of Technology, Department of Mechanical Engineering, Jaipur, \\ Rajasthan, India, e - mail: agrawal.drg@gmail.com \\ ${ }^{3}$ Shri Govindram Seksaria Institute of Technology and Science, Department of Mechanical \\ Engineering, Indore, Madhya Pradesh, India, e - mail: swatil8may@yahoo.co.in
}

\begin{abstract}
The PMS-EDDG is an effective hybrid process to beat the problems identified in machining of Inconel 600 through the conventional machining process. This hybrid-machining-process is a combination of SDG and Powder Mixed-EDM process. Modeling, comparative investigation, determination of optimal setting of process factors, and various surface developments in S-EDDG of Inconel 600 with chromium and absence of chromium-powder blended dielectric fluid (DF) have been narrated in this research work. One set of 31 experiments with chromium-powder and another set of 31 experiments without chromium-powder mixed DF was conducted on this set-up in accordance with the C-C-R-D plan of experimentation. The developed models through RSM support to investigate the behavior of input process-factors over the responses. The input factors in this research work are ampere-current (I), pulse-on-time $\left(\mathrm{T}_{\mathrm{on}}\right)$, wheel speed (WS), and duty cycle (DC). The MRR and $R_{a}$ are the output-responses in this machining process. The optimum setting of process-parameters is computed through the integrated Grey-Taguchi based WPCA-approach. The confirmation experiment is conducted on this set-up at the optimum-condition and its results display the agreeable matching among the actual and predicted values. The WMPI is improved by 0.414 . The SEM investigation has been conducted at the optimum-condition on the produced machined-surfaces and on the produced white recast-layer thickness.
\end{abstract}

KEYWORDS: Analysis of variance (ANOVA); Powder Mixed Surface-Electro Diamond Discharge Grinding (PMS-EDDG); hybrid process; RSM; and Inconel 600.

\section{Introduction}

There are diverse applications in which Ni-based super-alloys are utilized adequately i.e. in aircraft, turbine components, nuclear reactor parts and in petrochemical equipments etc. as it has excellent properties like high strength, creep resistance, fatigue resistance at high temperature [1]. Ni-based Inconel 718 is difficult to machine material with conventional machining due to its higher hardness, toughness and less thermal conductivity [2]. This is why advanced hybrid machining process based on thermo-electric energy and mechanical energy is adopted here for ease machining of Inconel 600. Luo et al. [3] did the experimental work on ED-Machining of Chromium-12 steel and narrated that discharge transitivity in IEG relies upon the gap debris. They also described that debris not only supports in ignition process but also responsible for enhance the gap-size. Ho et al. [4] reported about the research trends in ED-Machining to raise the performance estimates, and optimization of process factors. They also reported the scope of ED-Machining uses is featured along with the advancement of HMprocesses. Lee et al. [5] conducted the experiments on ED-Machining with D-2 and H-13 tool steels. They reported an investigation about the connection among the ED-Machining factors 
and surface-cracks by utilizing the factorial-design, based on the $\mathrm{T}_{\mathrm{on}}$, and ampere-current factors. Kao et al. [6] performed the experiments and narrated that Grey-TM integrated methodology improves the multi-output-characteristics of the process in ED-Machining of Ti6Al-4V. Tzeng et al. [7] did experimental work on ED-Machining with SKD-11 steel. They choose aluminum, chromium, copper, and silicon-carbide powders for this work and observed that aluminum powder make the greatest gap size, trailed by $\mathrm{Cr}$, than $\mathrm{Si}-\mathrm{C}$ and with $\mathrm{Cu}$ has the lowest gap size. George et al. [8] utilized the TM technique to determine the optimal setting of process factors in ED-Machining of Carbon-Carbon composite. Modi et al. [9] utilized DA technique for the development of MRR, and SR models in hole-drilling operational work on PM-ED Machining. He also investigated the impact of process factors on the process outcomes. Singh et al. [10] conducted experiments and utilized Grey-TM method for multi-output optimization of process factors in F-EDDG with Tungsten Carbide-Co composite-work material. Gauri et al. [11] utilized various multi-response optimization methodologies on W-ED Machining data sets and also distinguished the performance obtained from these methodologies. Lin et al. [12] utilized Grey-Fuzzy technique for multiresponse optimization of process factors in ED-Machining with SKD-11 steel. Modi et al. [13] described the details of PMEDM with grinding attachment process and determined the optimum setting of process parameters through WPCA method. Modi et al. [14] did the experiments on EDDSG with Ti6AL4V. They reported that Grey-TM methodology enhances the machining performance. Chen et al. [15] performed the experimental work on EDMachining of Ti6Al4V work material with distilled water and with kerosene. They also reported about the material removal mechanism in distilled water and in kerosene. Liao et al. [16] clarified that there are a few weaknesses in PCA procedure. He utilized WPC Approach to beat these inadequacies and used this technique for multi-response-optimization. Kumar et al. [17] conducted the experiment on various titanium alloys in PMED-M process and study the effect of cryogenic treatment on TWR. He also developed the model of TWR by using DA. Ramesh et al. [18] did experimental work on PBED-Machining of AISI P-20 steel. They reported that the impact of various powders and diverse electrode materials on PBED-M process performance. Modi et al. [19] conducted the experiments on EDDSG with Ti6A14V and reported that the effect of input parameters on the output response. Modi et al. [20] performed the tests on EDDS-G with titanium alloy and repoted that the influence of dielectric jet flushing on the responses. Kumar et al. [21] conducted experiments on PMEDMachining of Inconel 800 and utilized RSM technique for the development of MRR and TW$\mathrm{R}$ models. They utilized desirability technique for multi-response optimization of process factors. Modi et al. [22] conducted the experiments on lathe with HSS and utilized the Taguchi's method for modeling and optimization of machining parameters. Modi et al. [23] did the experiments on drilling machine with Al-SiC composite and utilized Taguchi's Method to determine the optimum setting of process parameters. Prakash et al. [24] performed the experimental work on PMED-Machining of Ti35Nb7Ta5Zr $\beta-\mathrm{Ti}$ alloy with silicon powder blended DF. They observed that PAED-Machining enhance the process-performance. Razak et al. [25] did the experimental work on PMED-Machining of Mg-alloy and revealed that $\mathrm{Zn}$ blended DF alters the rate of corrosion of Mg-alloy. Modi et al. [26] did the experimental work on PMEDM with Nimonic 80A with Al, and $\mathrm{Cr}$ powder mixed dielectric fluid. They reported that effectiveness of ED Machining is influenced by the properties of added powders in dielectric fluid. Modi et al. [27] performed the tests on EDDS-G of titanium alloy with SiC powder mixed DF. They applied integrated multi-output optimization methodology to determine the optimum setting of process variables and reported that the integrated statistical methodology enhances the multi-output performance index by 0.375 . De et al. [28] conducted the tests on WEDM with sintered titanium. They studied the effect of various parameters i.e., pulse on time, pulse off time, wire feed, and wire tension on MRR, SR, kerf width, and over 
cut. They applied RSM for the development of mathematical model of the responses. Raturi et al. [29] did the tests on WEDM with $\mathrm{Al} 6063 / \mathrm{SiC} / \mathrm{Al} 2 \mathrm{O} 3$ composite. They reported that the MRR and SR increase with increase in \% weight fraction of $\mathrm{SiC}$ and $\mathrm{Al} 2 \mathrm{O} 3$ particles in MMCs and HMMCs. Umacharan et al. [30] did experimental work on electro dischargediamond-drilling with nimonic-alloy and utilized GRA-PCA technique for multi-objectiveoptimization of process factors. H-M-P performance is more adequate than the individual performance of adjoining process with same input factors [31, 32].

Based on the literature review, the surface grinding of Inconel 600 in S-EDDG process with chromium and absence of chromium powder blended with dielectric-fluid is the field under development. The aim of this work is to thorough investigate the mechanism of machining of Inconel 600 utilizing the PMS-EDDG process, formulate the empirical models of the process-responses with chromium and absence of chromium powder blended with DF in S-EDDG of Inconel 600, comparative study to analyze the behaviour of input process factors against the process-responses, determination of optimum condition of process parameters with $\mathrm{Cr}$ powder mixed dielectric fluid by utilizing integrated Grey-TM based WPCA method, and finally examine the effect of presence and absence of chromium powder in dielectric fluid on S-EDDG produced surfaces and on the WRL thickness at the optimum condition.

To fulfil these aims, one-set of 31 experiments with chromium powder and another set of 31 experiments without $\mathrm{Cr}$ powder blended dielectric fluid were conducted on S-EDDG setup. The mathematical models of the responses were developed using the RSM. These developed empirical models have been utilized to study and compare the behaviour of input process factors against the responses with chromium and absence of chromium powder blended DF. TM is not fit for multi-response optimization of process factors in PMS-EDDG of Inconel 600. This is why the Grey-TM based WPCA approach has been utilized for the determination of the optimum combination of machining variables with chromium powder blended DF in S-EDDG of Inconel 600. This integrated optimization approach suggested an optimum setting of process parameters which helps the engineer to develop a cost-effective process. The SEM investigations have been conducted to study the effect of presence and absence of $\mathrm{Cr}$ powder in the dielectric fluid on S-EDDG produced surfaces and on the WRL thickness.

\section{Experimental-Procedure with PMS-EDDG process}

Two sets of thirty-one experiments were conducted in accordance to Central-CompositeRotary-Design plan of experimentation on in-house composed and created PMS-EDDG frame-up with Inconel 600 work-piece. The illustrative drawing and photographic image of PMS-EDDG set-up is displayed in "Figs. 1 and 2" respectively. The thirty-one tests were conducted on this frame-up with chromium powder blended DF. Another set of thirty-one experimentations was conducted on the same frame-up without chromium powder blended DF. The input factors associated with this research work were ampere-current, $\mathrm{T}_{\text {on }}, \mathrm{S}$, and duty-cycle.

Contingent on starting test outcomes and ED-Machining limit, the levels of factors were picked as depicted in Table 1. The chromium powder concentration was taken $3 \mathrm{gram} / \mathrm{litre}$ in the dielectric fluid. The Inconel 600 was chosen as the work-material which is rectangular and flat in shape. The structure of Inconel 600 work-material is Nickel, $\mathrm{Cr}=15$ $\%, \mathrm{Fe}=8 \%, \mathrm{~V}=3.7 \%, \mathrm{C}=0.15 \%, \mathrm{Mn}=1 \%, \mathrm{~S}=0.015 \%, \mathrm{Si}=0.5 \%$ and $\mathrm{Cu}=0.5 \%$. The size of the work-piece is $60 \mathrm{~mm} \times 10 \mathrm{~mm} \times 10 \mathrm{~mm}$.

The "Eq. (1)" was utilized to compute the MRR ( $\mathrm{mm}^{3} /$ minute). 


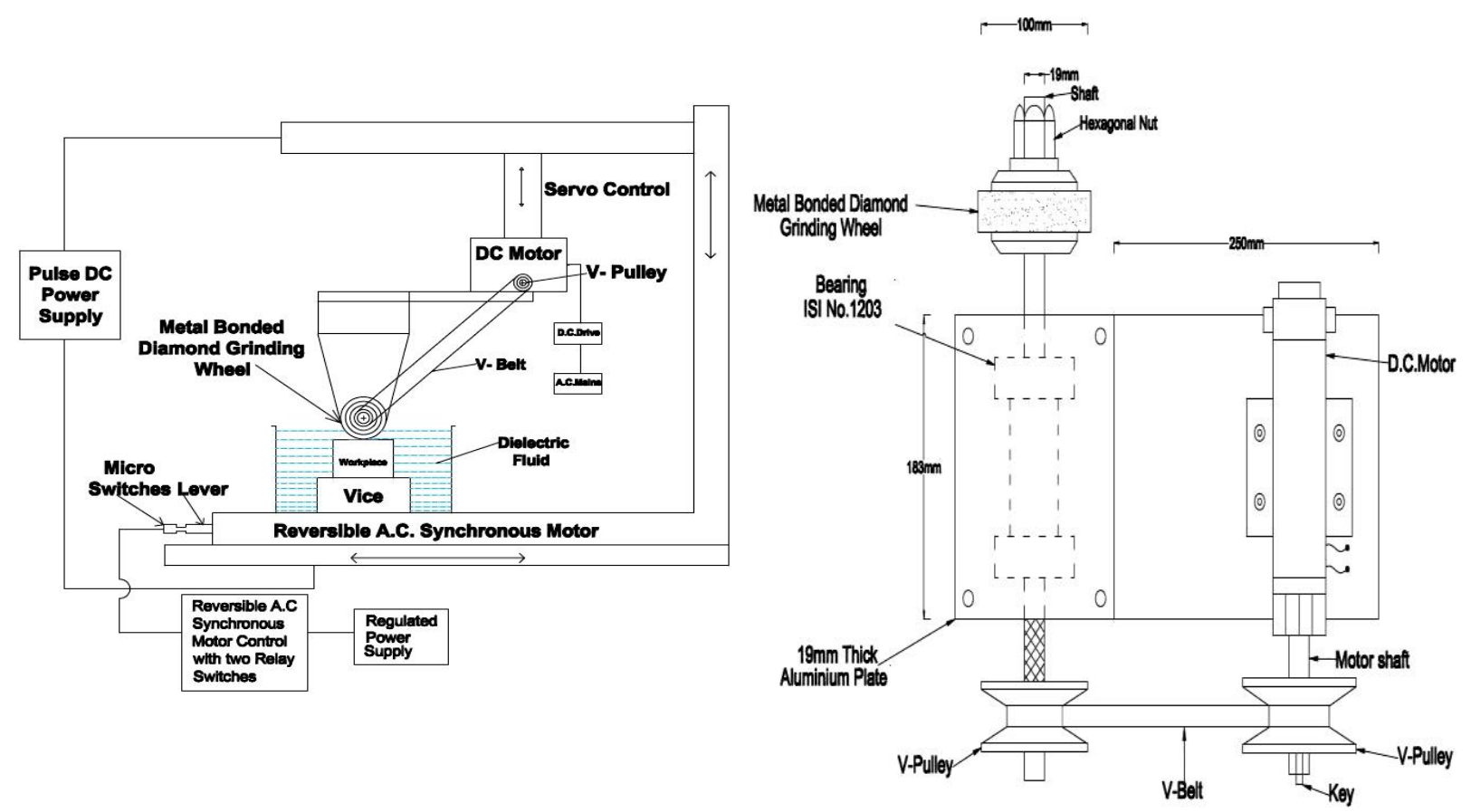

Fig. 1. Illustrative drawing of PMS-EDDG attachment.

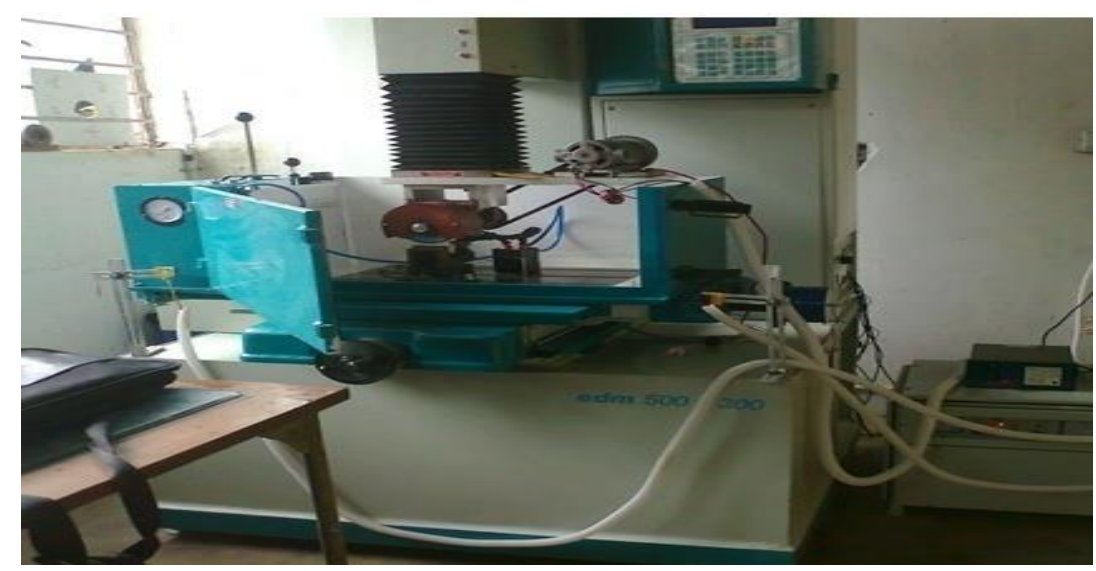

Fig. 2. Photographic image of PMS-EDDG attachment.

$\operatorname{MRR}\left(\mathrm{mm}^{3} /\right.$ minute $)=\frac{\text { Difference in weight of } w / p \text { before and after the machining } \times 1000}{t \times \rho}$

The machining time $(\mathrm{t})$ in this process is equal to 60 minutes; the density of the work piece material $(\rho)$ is equal to $8.47 \mathrm{gm} / \mathrm{cm}^{3}$. The electronic balance was used for the measurement of weight. The Surtronic-25 SR analyzer at a cut-off estimation of $0.8 \mathrm{~mm}$ was utilized for the estimation of $\mathrm{R}_{\mathrm{a}}$. The advanced tachometer was utilized for measurement of wheel-speed. The content of bronze G-wheel diamond bonded is listed in Table 2.

Table 1. Input machining factors involved in this experimental work and its range

\begin{tabular}{cccccc}
\hline Parameters & -2 & -1 & 0 & +1 & +2 \\
\hline Current $(\mathrm{I})$ & 1 & 3 & 5 & 7 & 9 \\
\hline Pulse-on-time $\left(\mathrm{T}_{\text {on }}\right)$ & 100 & 125 & 150 & 175 & 200 \\
\hline Wheel-Speed $(\mathrm{S})$ & 200 & 400 & 600 & 800 & 1000 \\
\hline Duty-Cycle (DC) & 0.61 & 0.65 & 0.69 & 0.73 & 0.77 \\
\hline
\end{tabular}


Table 2. Content of bronze G-wheel diamond bonded

\begin{tabular}{lccccccc}
\hline Abrasive & $\begin{array}{c}\text { Diameter } \\
\text { in } \mathrm{mm}\end{array}$ & $\begin{array}{c}\text { Thickness } \\
\text { in } \mathrm{mm}\end{array}$ & $\begin{array}{c}\text { Bond } \\
\text { Material }\end{array}$ & $\begin{array}{c}\text { Concentration } \\
\%\end{array}$ & $\begin{array}{c}\text { Bore } \\
\text { in } \mathrm{mm}\end{array}$ & $\begin{array}{c}\text { Depth of } \\
\text { abrasive in } \mathrm{mm}\end{array}$ & $\begin{array}{c}\text { Grit } \\
\text { size }\end{array}$ \\
\hline Diamond & 100 & 10 & Bronze & 80 & 32 & 5 & $80 / 100$ \\
\hline
\end{tabular}

\section{Response Surface Modeling (RSM)}

RSM is an accumulation of statistical and mathematical methodologies. This methodology is applied to acquire the connection among the factors associated with machining process and the process-responses in PMS-EDDG of Inconel 600 with chromium and absence of chromium powder blended DF [23].

The "Eq. (2)" is used to express the surface-response.

$$
Y=a_{0}+\sum_{i=1}^{n} a_{i} x_{i}+\sum_{i=1}^{n} a_{i i} x_{i}^{2}+\sum_{j>i} a_{i j} x_{i} x_{j}
$$

Here, $Y=$ Output Responses, $a_{o}=$ Free-terms coefficient, $a_{i}=$ Linear-terms coefficient, $a_{i i}=$ Quadratic-terms coefficient, and $a_{i j}=$ Interaction-terms coefficient.

\section{Mathematical Modelling of Experimental Responses with $\mathrm{Cr}$ powder mixed dielectric-fluid}

The first set of thirty-one experiments was conducted on S-EDDG of Inconel 600 with chromium powder blended DF. The estimation of all the factors associated with this experimentation work is displayed in Table 1.The C-C-R-D experimentation plan is depicted in Table 3. This C-C-R-D design consist of sixteen corner points at the interval of $[-1,1]$, Eight axial points at the interval of $[-2,2]$, and the central point at zero level reiterate seven times. This includes the total 31 experimental runs. The 'Design Expert 8.0.7.1' [33] was used for the development of mathematical models of MRR and $R_{a}$. After removal of non-valuable terms, the numerical models of MRR and $\mathrm{R}_{\mathrm{a}}$ are depicted by the "Eqs. (3) and (4)".

$$
\begin{aligned}
& M R R=0.46+0.14 I+0.058 T_{\text {on }}+0.058 S-0.032 D C+0.028 I^{2} \\
& R_{a}=4.22+0.54 I+0.23 T_{o n}-0.26 S+0.61 D C-0.076 T_{o n}^{2}
\end{aligned}
$$

The different graphs were plotted to forecast the behavior of input process factors against the process outcomes utilizing the "Eqs. (3) and (4)".

\subsection{ANOVA analysis for MRR and $R_{a}$ model}

The ANOVA-outcomes for the MRR and $\mathrm{R}_{\mathrm{a}}$ are depicted in Tables 4 and 5 respectively. "Figs. 3 and 4" display the $\mathrm{N} \%$ probability graph of the residuals for MRR and $\mathrm{R}_{a}$ respectively and demonstrate that residuals scatter around the straight-line exhibiting that errors are N-distributed [34]. Moreover, from the "Figs. 5 and 6", it was noticed that the predicted values from the empirical model were seen to be in excellent matching with the actual values for MRR and $R_{a}$. The F-value of MRR and $R_{a}$ model with chromium powder blended DF is 300.63 and 203.27 respectively with value of $p<0.0001$ for both the models so that these developed empirical equations of $M R R$ and $R_{a}$ are adequate to depict the association among input machining variables and the output-responses. The R-squared values for MRR and $R_{a}$ model is 0.9836 and 0.9760 respectively, that indicates the developed models are significant in describing the variation of MRR and $\mathrm{R}_{\mathrm{a}}$ up-to $98.36 \%$ and $97.60 \%$. There is negligible difference between Adj R-Squared and Pred R-Squared value for both the 
models. The values of $\mathrm{CV}$ are 4.43 and 3.28 for MRR and $\mathrm{R}_{\mathrm{a}}$ model respectively. As the value of $\mathrm{CV}$ becomes smaller, it will indicate towards enhanced precision and consistency of experiments performed. The Adeq-Precision value for both the models is essentially higher than the required-one and hence indicates an adequate signal for both the models.

Table 3. C-C-R-D experimental-plan and process-responses with $\mathrm{Cr}$ powder blended DF

\begin{tabular}{|c|c|c|c|c|c|c|c|c|}
\hline $\begin{array}{c}\text { Exp. } \\
\text { Number }\end{array}$ & $\begin{array}{l}\text { Current } \\
(I) \\
\text { ampere }\end{array}$ & $\begin{array}{l}\text { Pulse- } \\
\text { on-time } \\
\left(T_{o n}\right) \mu \mathrm{s}\end{array}$ & $\begin{array}{l}\text { Wheel } \\
\text { Speed } \\
(S) \\
\text { RPM }\end{array}$ & $\begin{array}{l}\text { Duty } \\
\text { Cycle } \\
(D C)\end{array}$ & $\begin{array}{c}\text { MRR } \\
\left(\mathrm{mm}^{3} / \mathrm{min}\right) \\
\text { Experimenta } \\
1 \\
\end{array}$ & $\begin{array}{c}\text { MRR } \\
\left(\mathrm{mm}^{3} / \mathrm{min}\right) \\
\text { Predicted }\end{array}$ & $\begin{array}{c}\mathrm{R}_{\mathrm{a}} \\
(\mu \mathrm{m}) \\
\text { Experimental }\end{array}$ & $\begin{array}{c}\mathrm{R}_{\mathrm{a}} \\
(\mu \mathrm{m}) \\
\text { Predicted }\end{array}$ \\
\hline 1 & -1 & -1 & -1 & -1 & 0.279 & 0.264 & 3.21 & 3.024 \\
\hline 2 & 1 & -1 & -1 & -1 & 0.531 & 0.544 & 4.06 & 4.104 \\
\hline 3 & -1 & 1 & -1 & -1 & 0.370 & 0.380 & 3.36 & 3.484 \\
\hline 4 & 1 & 1 & -1 & -1 & 0.642 & 0.660 & 4.49 & 4.564 \\
\hline 5 & -1 & -1 & 1 & -1 & 0.368 & 0.380 & 2.58 & 2.504 \\
\hline 6 & 1 & -1 & 1 & -1 & 0.644 & 0.660 & 3.42 & 3.584 \\
\hline 7 & -1 & 1 & 1 & -1 & 0.494 & 0.496 & 3.04 & 2.964 \\
\hline 8 & 1 & 1 & 1 & -1 & 0.768 & 0.776 & 4.05 & 4.044 \\
\hline 9 & -1 & -1 & -1 & 1 & 0.198 & 0.200 & 4.35 & 4.244 \\
\hline 10 & 1 & -1 & -1 & 1 & 0.464 & 0.480 & 5.47 & 5.324 \\
\hline 11 & -1 & 1 & -1 & 1 & 0.305 & 0.316 & 4.69 & 4.704 \\
\hline 12 & 1 & 1 & -1 & 1 & 0.589 & 0.596 & 5.99 & 5.784 \\
\hline 13 & -1 & -1 & 1 & 1 & 0.321 & 0.316 & 3.73 & 3.724 \\
\hline 14 & 1 & -1 & 1 & 1 & 0.598 & 0.596 & 4.76 & 4.804 \\
\hline 15 & -1 & 1 & 1 & 1 & 0.419 & 0.432 & 4.32 & 4.184 \\
\hline 16 & 1 & 1 & 1 & 1 & 0.712 & 0.712 & 5.38 & 5.264 \\
\hline 17 & -2 & 0 & 0 & 0 & 0.289 & 0.292 & 2.89 & 3.140 \\
\hline 18 & 2 & 0 & 0 & 0 & 0.858 & 0.852 & 5.17 & 5.300 \\
\hline 19 & 0 & -2 & 0 & 0 & 0.360 & 0.344 & 3.38 & 3.456 \\
\hline 20 & 0 & 2 & 0 & 0 & 0.605 & 0.576 & 4.30 & 4.376 \\
\hline 21 & 0 & 0 & -2 & 0 & 0.323 & 0.344 & 4.81 & 4.740 \\
\hline 22 & 0 & 0 & 2 & 0 & 0.542 & 0.576 & 3.82 & 3.700 \\
\hline 23 & 0 & 0 & 0 & -2 & 0.531 & 0.524 & 3.26 & 3.000 \\
\hline 24 & 0 & 0 & 0 & 2 & 0.389 & 0.396 & 5.29 & 5.440 \\
\hline 25 & 0 & 0 & 0 & 0 & 0.457 & 0.460 & 4.16 & 4.220 \\
\hline 26 & 0 & 0 & 0 & 0 & 0.511 & 0.460 & 4.17 & 4.220 \\
\hline 27 & 0 & 0 & 0 & 0 & 0.436 & 0.460 & 4.24 & 4.220 \\
\hline 28 & 0 & 0 & 0 & 0 & 0.455 & 0.460 & 4.14 & 4.220 \\
\hline 29 & 0 & 0 & 0 & 0 & 0.462 & 0.460 & 4.08 & 4.220 \\
\hline 30 & 0 & 0 & 0 & 0 & 0.478 & 0.460 & 4.07 & 4.220 \\
\hline 31 & 0 & 0 & 0 & 0 & 0.401 & 0.460 & 4.29 & 4.220 \\
\hline
\end{tabular}

\section{Mathematical Modelling of Experimental Responses without Cr powder mixed dielectric-fluid}

The second set of thirty-one experiments was conducted on S-EDDG of Inconel 600 without chromium powder blended DF. The estimation of all the factors related with this experimentation work is displayed in Table 1. The C-C-R-D experimentation plan is depicted in Table 6. The 'Design Expert 8.0.7.1' [23] was used for the development of mathematical models of MRR and $\mathrm{R}_{\mathrm{a}}$ in S-EDDG of Inconel 600 without chromium powder mixed dielectric fluid. After elimination of non-valuable terms, the mathematical models of MRR and $\mathrm{R}_{\mathrm{a}}$ are depicted by the "Eqs. (5) and (6)".

$$
M R R=0.42+0.13 I+0.053 T_{\text {on }}+0.053 S-0.030 D C+0.026 I^{2}
$$




$$
R_{a}=4.27+0.55 I+0.23 T_{o n}-0.27 S+0.62 D C
$$

Table 4. ANOVA and Response-table for MRR with $\mathrm{Cr}$ powder mixed dielectric fluid

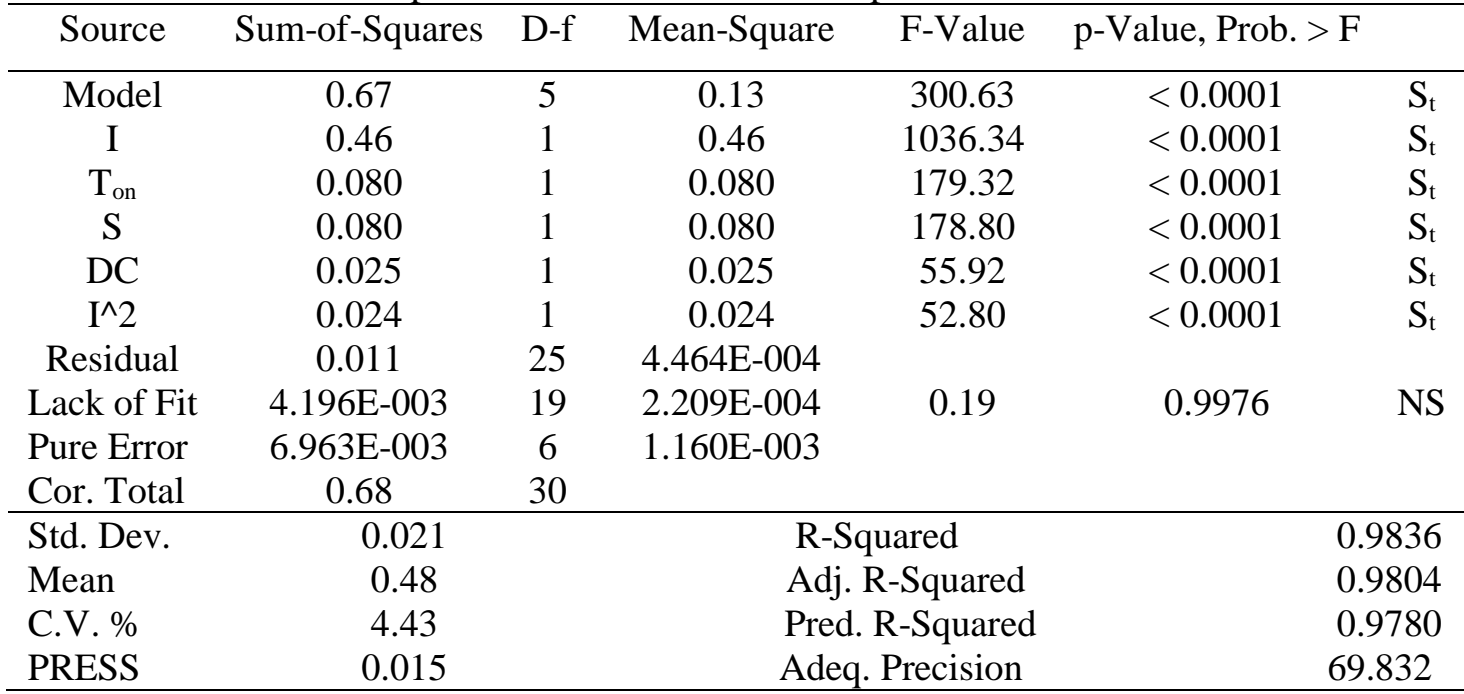

Table 5. ANOVA and Response-table for $\mathrm{R}_{\mathrm{a}}$ with $\mathrm{Cr}$ powder mixed dielectric fluid

\begin{tabular}{|c|c|c|c|c|c|c|}
\hline Source & Sum-of-Squares & D-f & Mean-Square & F-Value & p-Value, Prob. & \\
\hline Model & 18.87 & 5 & 3.77 & 203.27 & $<0.0001$ & $\mathrm{~S}_{\mathrm{t}}$ \\
\hline I & 6.93 & 1 & 6.93 & 373.41 & $<0.0001$ & $S_{t}$ \\
\hline$T_{\text {on }}$ & 1.30 & 1 & 1.30 & 69.87 & $<0.0001$ & $S_{t}$ \\
\hline $\mathrm{S}$ & 1.66 & 1 & 1.66 & 89.63 & $<0.0001$ & $\mathrm{~S}_{\mathrm{t}}$ \\
\hline DC & 8.81 & 1 & 8.81 & 474.39 & $<0.0001$ & $\mathrm{~S}_{\mathrm{t}}$ \\
\hline $\mathrm{T}_{\mathrm{on}} \wedge 2$ & 0.17 & 1 & 0.17 & 9.08 & 0.0058 & $\mathrm{~S}_{\mathrm{t}}$ \\
\hline Residual & 0.46 & 25 & 0.019 & & & \\
\hline Lack of Fit & 0.43 & 19 & 0.022 & 3.52 & 0.0625 & NS \\
\hline Pure Error & 0.038 & 6 & $6.362 \mathrm{E}-003$ & & & \\
\hline Cor. Total & 19.34 & 30 & & & & \\
\hline Std. Dev. & 0.14 & & \multicolumn{3}{|c|}{ R-Squar } & 0.9760 \\
\hline Mean & 4.16 & & \multicolumn{3}{|c|}{ Adj. R-Squared } & 0.9712 \\
\hline C.V. \% & 3.28 & & \multicolumn{3}{|c|}{ Pred. R-Squared } & 0.9610 \\
\hline PRESS & 0.75 & & \multicolumn{3}{|c|}{ Adeq. Precision } & 54.685 \\
\hline
\end{tabular}

Table 6. C-C-R-D experimental-plan and process-responses without $\mathrm{Cr}$ powder mixed dielectric fluid

\begin{tabular}{ccccccccc}
\hline $\begin{array}{c}\text { Exp. } \\
\text { Number }\end{array}$ & $\begin{array}{c}\text { Current } \\
(I) \\
\text { ampere }\end{array}$ & $\begin{array}{c}\text { Pulse } \\
\text { on-time } \\
\left(T_{\text {on }}\right)\end{array}$ & $\begin{array}{c}\text { Wheel } \\
\text { Speed } \\
(S)\end{array}$ & $\begin{array}{c}\text { Duty } \\
\text { Cycle } \\
(D C\end{array}$ & $\begin{array}{c}\text { MRR } \\
\left(\mathrm{mm}^{3} / \mathrm{min}\right) \\
\text { Experimental }\end{array}$ & $\begin{array}{c}\text { MRR } \\
\left(\mathrm{mm}^{3} / \mathrm{min}\right) \\
\text { Predicted }\end{array}$ & $\begin{array}{c}\mathrm{R}_{\mathrm{a}}(\mu \mathrm{m}) \\
\text { Experimental }\end{array}$ & $\begin{array}{c}\mathrm{R}_{\mathrm{a}} \\
(\mu \mathrm{m}) \\
\text { Predicted }\end{array}$ \\
\hline 1 & -1 & -1 & -1 & -1 & 0.255 & 0.240 & 3.37 & 3.14 \\
2 & 1 & -1 & -1 & -1 & 0.485 & 0.500 & 4.26 & 4.24 \\
3 & -1 & 1 & -1 & -1 & 0.338 & 0.346 & 3.52 & 3.60 \\
4 & 1 & 1 & -1 & -1 & 0.586 & 0.606 & 4.70 & 4.70 \\
5 & -1 & -1 & 1 & -1 & 0.336 & 0.346 & 2.70 & 2.60 \\
6 & 1 & -1 & 1 & -1 & 0.588 & 0.606 & 3.579 & 3.70 \\
7 & -1 & 1 & 1 & -1 & 0.451 & 0.452 & 3.18 & 3.06 \\
8 & 1 & 1 & 1 & -1 & 0.701 & 0.712 & 4.23 & 4.16 \\
9 & -1 & -1 & -1 & 1 & 0.180 & 0.180 & 4.54 & 4.38 \\
10 & 1 & -1 & -1 & 1 & 0.424 & 0.440 & 5.70 & 5.48 \\
11 & -1 & 1 & -1 & 1 & 0.278 & 0.296 & 4.88 & 4.84
\end{tabular}




\begin{tabular}{ccccccccc}
\hline 12 & 1 & 1 & -1 & 1 & 0.538 & 0.546 & 6.23 & 5.94 \\
13 & -1 & -1 & 1 & 1 & 0.293 & 0.286 & 3.879 & 3.84 \\
14 & 1 & -1 & 1 & 1 & 0.546 & 0.546 & 4.95 & 4.94 \\
15 & -1 & 1 & 1 & 1 & 0.382 & 0.392 & 4.49 & 4.30 \\
16 & 1 & 1 & 1 & 1 & 0.650 & 0.652 & 5.59 & 5.40 \\
17 & -2 & 0 & 0 & 0 & 0.264 & 0.264 & 3.00 & 3.10 \\
18 & 2 & 0 & 0 & 0 & 0.784 & 0.784 & 5.36 & 5.37 \\
19 & 0 & -2 & 0 & 0 & 0.329 & 0.314 & 3.50 & 3.81 \\
20 & 0 & 2 & 0 & 0 & 0.552 & 0.526 & 4.45 & 4.73 \\
21 & 0 & 0 & -2 & 0 & 0.295 & 0.314 & 4.97 & 4.81 \\
22 & 0 & 0 & 2 & 0 & 0.495 & 0.526 & 3.947 & 3.73 \\
23 & 0 & 0 & 0 & -2 & 0.485 & 0.480 & 3.36 & 3.03 \\
24 & 0 & 0 & 0 & 2 & 0.355 & 0.360 & 5.45 & 5.51 \\
25 & 0 & 0 & 0 & 0 & 0.417 & 0.420 & 4.28 & 4.27 \\
26 & 0 & 0 & 0 & 0 & 0.467 & 0.420 & 4.29 & 4.27 \\
27 & 0 & 0 & 0 & 0 & 0.398 & 0.420 & 4.36 & 4.27 \\
28 & 0 & 0 & 0 & 0 & 0.415 & 0.420 & 4.25 & 4.27 \\
29 & 0 & 0 & 0 & 0 & 0.422 & 0.420 & 4.18 & 4.27 \\
30 & 0 & 0 & 0 & 0 & 0.436 & 0.420 & 4.169 & 4.27 \\
31 & 0 & 0 & 0 & 0 & 0.369 & 0.420 & 4.39 & 4.27 \\
\hline
\end{tabular}

Table 7. ANOVA and Response-table for MRR without $\mathrm{Cr}$ powder mixed dielectric fluid

\begin{tabular}{ccccccc}
\hline Source & Sum-of-Squares & D-f & Mean-Square & F-Value & p-Value, Prob. $>\mathrm{F}$ & \\
\hline Model & 0.56 & 14 & 0.040 & 99.72 & $<0.0001$ & $\mathrm{~S}_{\mathrm{t}}$ \\
$\mathrm{I}$ & 0.39 & 1 & 0.39 & 958.87 & $<0.0001$ & $\mathrm{~S}_{\mathrm{t}}$ \\
$\mathrm{T}_{\text {on }}$ & 0.066 & 1 & 0.066 & 164.96 & $<0.0001$ & $\mathrm{~S}_{\mathrm{t}}$ \\
$\mathrm{S}$ & 0.066 & 1 & 0.066 & 164.96 & $<0.0001$ & $\mathrm{~S}_{\mathrm{t}}$ \\
$\mathrm{DC}$ & 0.021 & 1 & 0.021 & 51.98 & $<0.0001$ & $\mathrm{~S}_{\mathrm{t}}$ \\
$\mathrm{I}^{\wedge} 2$ & 0.019 & 1 & 0.019 & 46.75 & $<0.0001$ & $\mathrm{~S}_{\mathrm{t}}$ \\
Residual & $6.447 \mathrm{E}-003$ & 16 & $4.029 \mathrm{E}-004$ & & & \\
Lack of Fit & $8.951 \mathrm{E}-004$ & 10 & $8.951 \mathrm{E}-005$ & 0.097 & 0.9992 & $\mathrm{NS}$ \\
Pure Error & $5.551 \mathrm{E}-003$ & 6 & $9.252 \mathrm{E}-004$ & & & \\
Cor. Total & 0.57 & 30 & & & & 0.9887 \\
\hline Std. Dev. & 0.020 & \multicolumn{7}{c}{ R-Squared } & & 0.9788 \\
Mean & 0.44 & Adj. R-Squared & & 0.9777 \\
C.V. \% & 4.60 & Pred. R-Squared & & 42.420 \\
PRESS & 0.013 & Adeq. Precision & & \\
\hline
\end{tabular}

Table 8. ANOVA and Response-table for $\mathrm{R}_{\mathrm{a}}$ without $\mathrm{Cr}$ powder mixed dielectric fluid

\begin{tabular}{|c|c|c|c|c|c|c|}
\hline Source & Sum-of-Squares & $\mathrm{d}-\mathrm{f}$ & Mean-Square & F-Value & p-Value, Prob. > F & \\
\hline Model & 20.40 & 14 & 1.46 & 93.35 & $<0.0001$ & $\mathrm{~S}_{\mathrm{t}}$ \\
\hline I & 7.48 & 1 & 7.48 & 479.32 & $<0.0001$ & $\mathrm{~S}_{\mathrm{t}}$ \\
\hline $\mathrm{T}_{\text {on }}$ & 1.37 & 1 & 1.37 & 88.01 & $<0.0001$ & $\mathrm{~S}_{\mathrm{t}}$ \\
\hline $\mathrm{S}$ & 1.84 & 1 & 1.84 & 117.98 & $<0.0001$ & $\mathrm{~S}_{\mathrm{t}}$ \\
\hline DC & 9.25 & 1 & 9.25 & 592.63 & $<0.0001$ & $\mathrm{~S}_{\mathrm{t}}$ \\
\hline $\mathrm{T}_{\mathrm{on}} \wedge 2$ & 0.092 & 1 & 0.092 & 5.92 & 0.0271 & NS \\
\hline Residual & 0.25 & 16 & 0.016 & & & \\
\hline Lack of Fit & 0.21 & 10 & 0.021 & 3.00 & 0.0955 & NS \\
\hline Pure Error & 0.042 & 6 & $6.930 \mathrm{E}-003$ & & & \\
\hline Cor. Total & 20.65 & 30 & & & & \\
\hline Std. Dev. & 0.12 & & R-Squared & & 0.9879 & \\
\hline Mean & 4.31 & & Adj. R-Squared & & 0.9773 & \\
\hline C.V. $\%$ & 2.90 & & Pred. R-Squared & & 0.9392 & \\
\hline PRESS & 1.26 & & Adeq. Precision & & 39.017 & \\
\hline
\end{tabular}


Table 8. ANOVA and Response-table for $\mathrm{R}_{\mathrm{a}}$ without $\mathrm{Cr}$ powder mixed dielectric fluid

\begin{tabular}{|c|c|c|c|c|c|c|}
\hline Source & Sum-of-Squares & d-f & Mean-Square & F-Value & p-Value, Prob. > F & \\
\hline Model & 20.40 & 14 & 1.46 & 93.35 & $<0.0001$ & $\mathrm{~S}_{\mathrm{t}}$ \\
\hline I & 7.48 & 1 & 7.48 & 479.32 & $<0.0001$ & $\mathrm{~S}_{\mathrm{t}}$ \\
\hline $\mathrm{T}_{\mathrm{on}}$ & 1.37 & 1 & 1.37 & 88.01 & $<0.0001$ & $\mathrm{~S}_{\mathrm{t}}$ \\
\hline $\mathrm{S}$ & 1.84 & 1 & 1.84 & 117.98 & $<0.0001$ & $\mathrm{~S}_{\mathrm{t}}$ \\
\hline $\mathrm{DC}$ & 9.25 & 1 & 9.25 & 592.63 & $<0.0001$ & $\mathrm{~S}_{\mathrm{t}}$ \\
\hline $\mathrm{T}_{\mathrm{on}} \wedge 2$ & 0.092 & 1 & 0.092 & 5.92 & 0.0271 & NS \\
\hline Residual & 0.25 & 16 & 0.016 & & & \\
\hline Lack of Fit & 0.21 & 10 & 0.021 & 3.00 & 0.0955 & NS \\
\hline Pure Error & 0.042 & 6 & 6.930E-003 & & & \\
\hline Cor. Total & 20.65 & 30 & & & & \\
\hline Std. Dev. & 0.12 & & R-Squared & & 0.9879 & \\
\hline Mean & 4.31 & & Adj. R-Squared & & 0.9773 & \\
\hline C.V. $\%$ & 2.90 & & Pred. R-Squared & & 0.9392 & \\
\hline PRESS & 1.26 & & Adeq. Precision & & 39.017 & \\
\hline
\end{tabular}

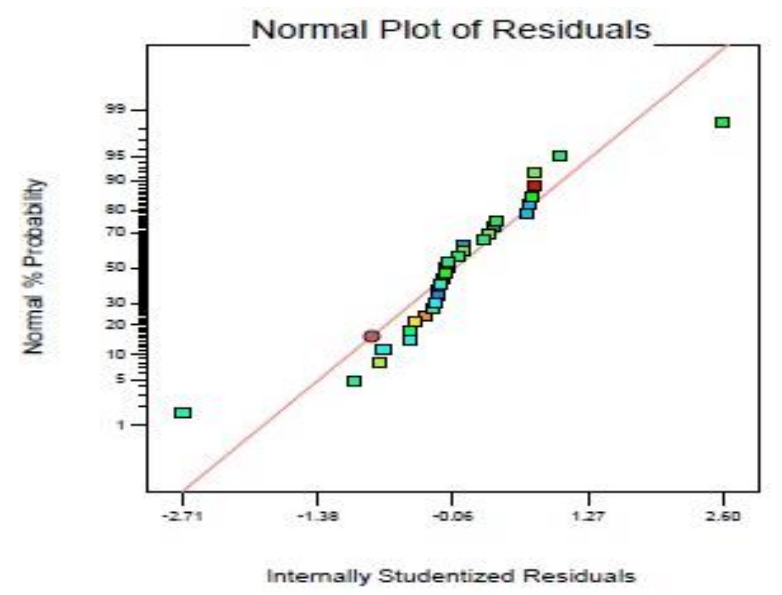

Fig. 3. N \% probability plot of residual for MRR with $\mathrm{Cr}$ powder.

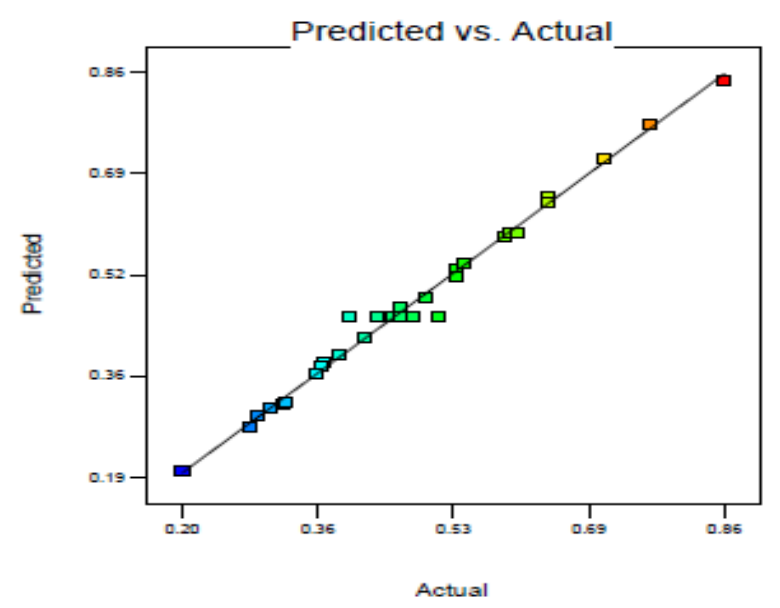

Fig. 5. Plot of actual and predicted output for MRR with $\mathrm{Cr}$ powder.

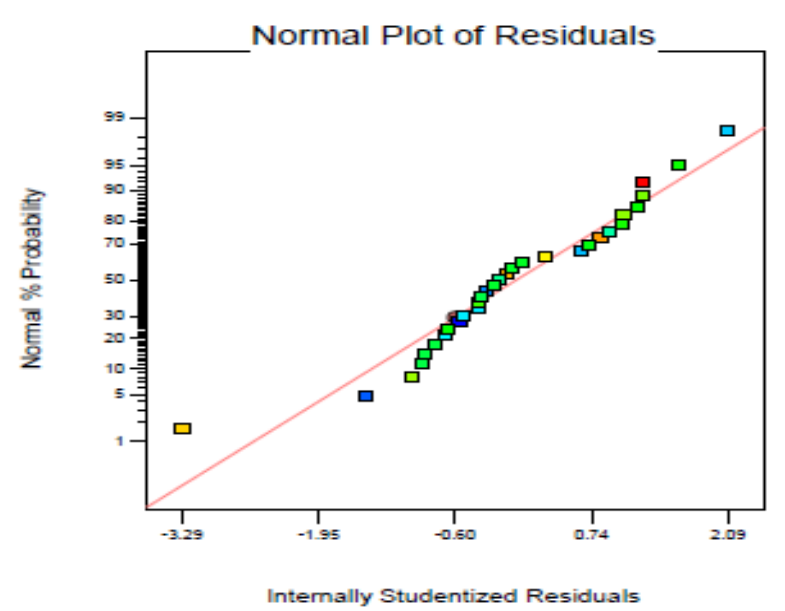

Fig. 4. $N \%$ probability plot of residual for $\mathrm{R}_{\mathrm{a}}$ with $\mathrm{Cr}$ powder.

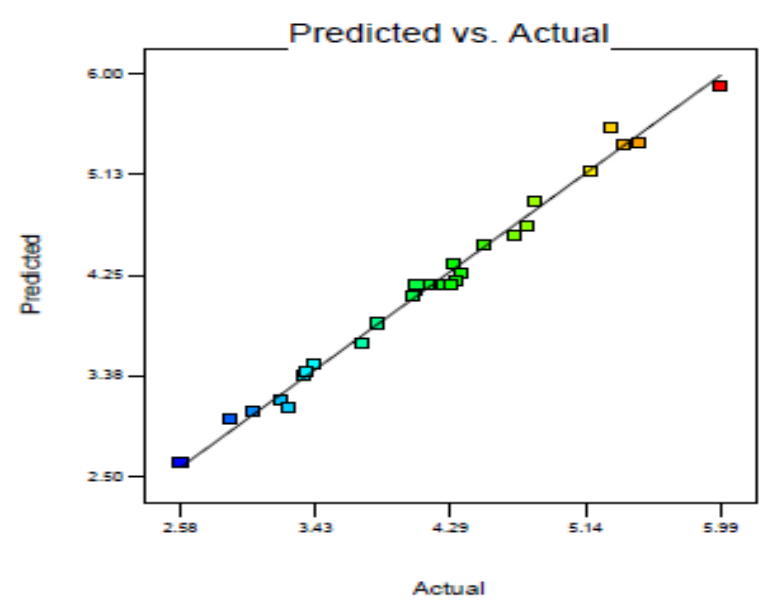

Fig. 6. Plot of actual and predicted output for $\mathrm{R}_{\mathrm{a}}$ with $\mathrm{Cr}$ powder. 


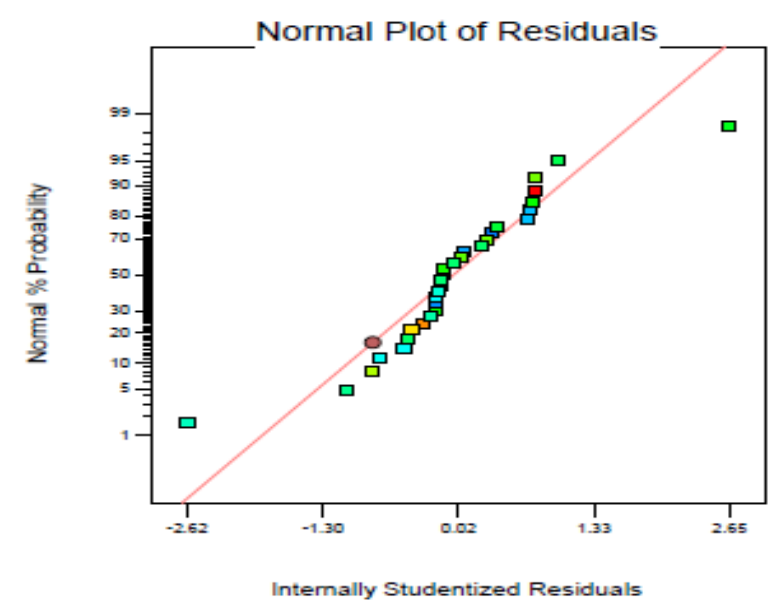

Fig. 7. N \% probability plot of residual for MRR without $\mathrm{Cr}$ powder

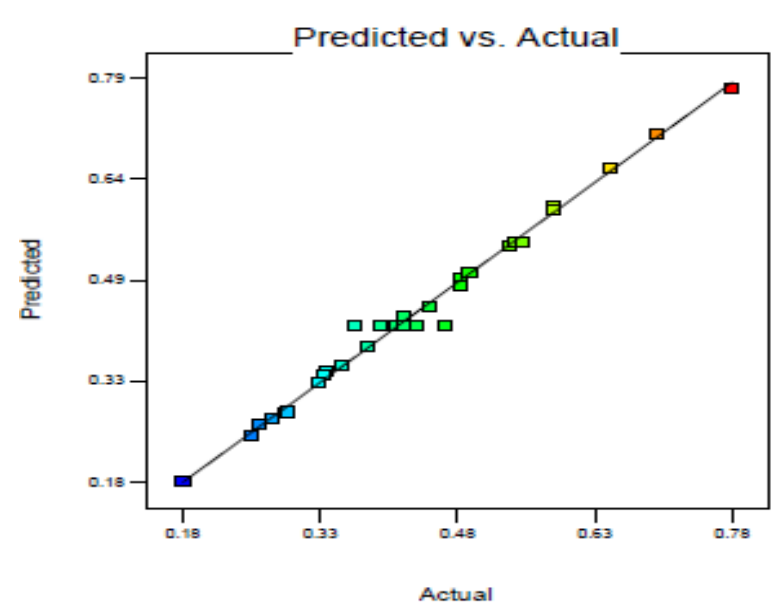

Fig. 9. Plot of actual and predicted output for output MRR without Cr powder.

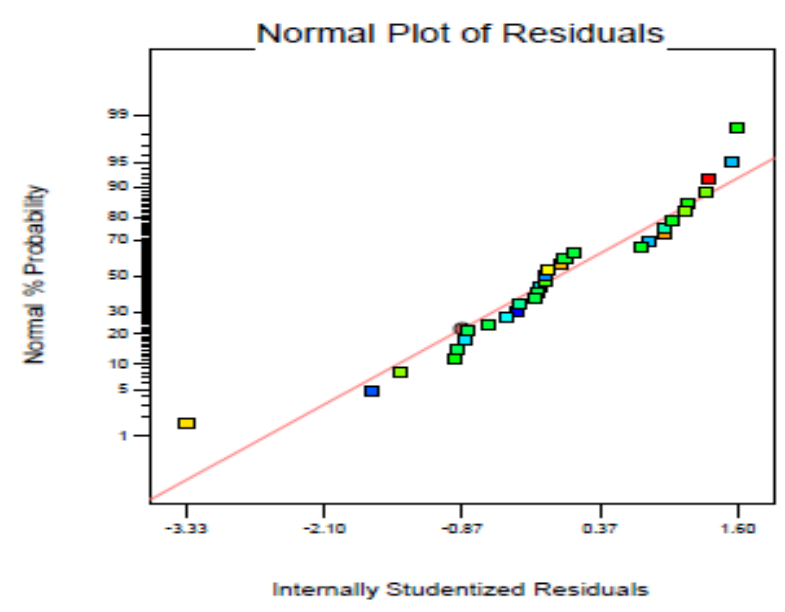

Fig. 8. N \% probability plot of residual for $\mathrm{R}_{\mathrm{a}}$ without $\mathrm{Cr}$ powder.

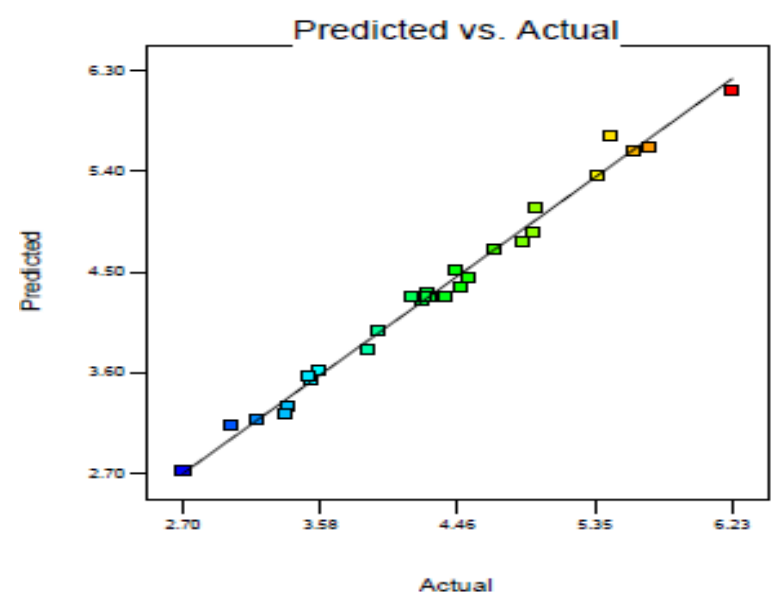

Fig. 10. Plot of actual and predicted for $\mathrm{R}_{\mathrm{a}}$ without $\mathrm{Cr}$ powder.

The distinctive charts were plotted to foresee the conduct of input process factors over the process-responses using the "Eqs. (5) and (6)".

\subsection{ANOVA analysis for MRR and Ra model}

The ANOVA outcomes for the MRR and $R_{a}$ are depicted in the Tables 7 and 8 respectively. The $\mathrm{N} \%$ probability graphs of residuals for MRR and $\mathrm{R}_{\mathrm{a}}$ are displayed by the "Figs. 7 and 8" respectively. In addition, the predicted values obtained through the developed model were observed to be a cognate with the actual experimental values for MRR and $R_{a}$ as depicted in "Figs. 9 and 10" respectively. The F-value of MRR and $\mathrm{R}_{\mathrm{a}}$ model with absence of chromium powder blended DF is 99.72 and 93.35 respectively with value of $p<0.0001$ for both the models so that these developed empirical equations of MRR and $\mathrm{R}_{\mathrm{a}}$ are also able to express the relation among the input machining factors and the responses. The R-squared values of MRR and $R_{a}$ model without chromium powder blended DF is 0.9887 and 0.9879 respectively indicates that the developed model are significant in describing the variation of MRR and $R_{a}$ up-to $98.87 \%$ and $98.79 \%$. There is negligible difference between Adj RSquared and Pred R-Squared value for both the models. The values of CV are 4.60 and 2.90 for MRR and $\mathrm{R}_{\mathrm{a}}$ model respectively. As $\mathrm{CV}$ becomes smaller in value, it will indicate towards improved precision and consistency of conducted experiments. The Adeq-Precision value for both the models is basically higher than the needed one and henceforth demonstrates a sufficient signal for both the models. 


\section{Analysis and interpretations of outcomes (from empirical models of MRR and $R_{a}$ with chromium and absence of chromium powder in dielectric)}

The investigation and interpretation of results are outlined here in Table 9 (refer the "Figs. 11 to 18 "). It is seen that the best outcomes are acquired in S-EDDG machining-process with chromium powder in DF. This is the reason; the optimum combination of process parameters in this process is calculated with $\mathrm{Cr}$ powder mixed condition.

\section{*Difference in MRR and $\mathbf{R}_{\mathrm{a}}$ in PMS-EDDG process with chromium and absence of $\mathbf{C r}$ Powder blended DF (refer Table 9)}

In the graphs from 11 to 14, the noticeable rise in MRR is seen in S-EDDG of Inconel 600 with chromium powder blended DF, as compared to the absence of powder in DF. The additional MRR is a direct result of the occurrence of series-discharge (along with sparkdischarge and grinding operation taken place among the bronze-wheel and Inconel 600 surface in S-EDDG machining-process without chromium powder blended DF) in the EG because of the presence of $\mathrm{Cr}$ powder in dielectric-fluid and consequently formed the chainlike structure of powder particles in the IEG. This chain-like structure of powder particles is responsible for bridging the space among the electrodes and finally, series discharge occurred in IEG.
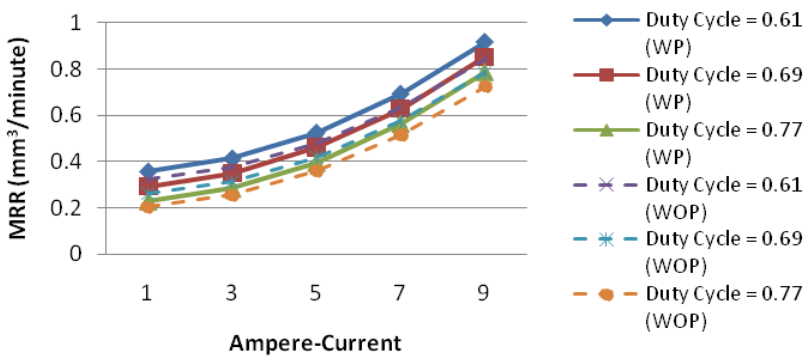

Fig. 11. Impact of ampere-current on MRR for various $\mathrm{DC}\left(\mathrm{WS}=600 \mathrm{rpm}, \mathrm{T}_{\mathrm{on}}=150 \mu \mathrm{s}\right)$
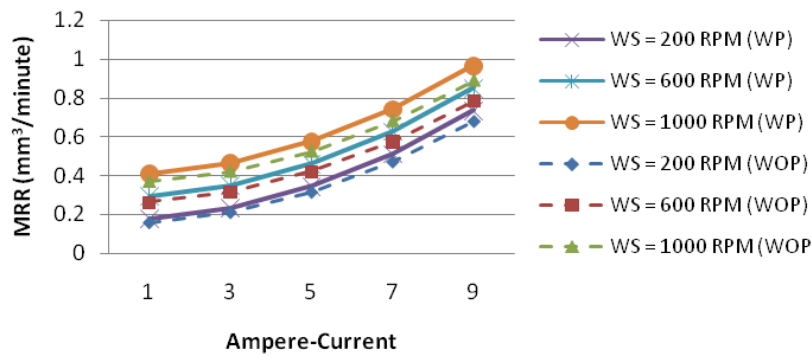

Fig. 13. Impact of ampere-current on MRR for various WS $\left(\mathrm{T}_{\mathrm{on}}=150 \mu \mathrm{s}, \mathrm{DC}=0.690\right)$

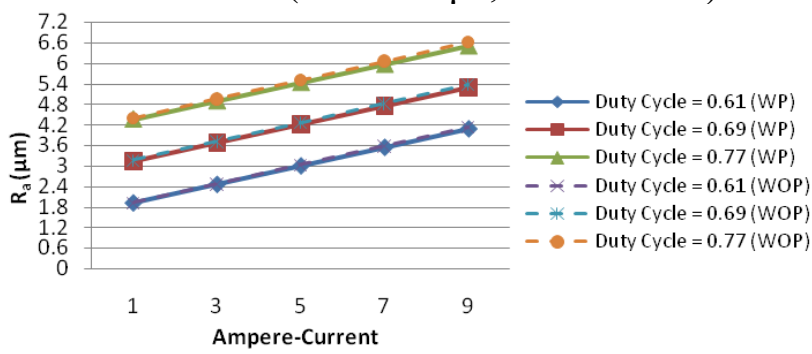

Fig. 15 Impact of ampere-current on $\mathrm{R}_{\mathrm{a}}$ for various DC (WS $\left.=600 \mathrm{rpm}, \mathrm{T}_{\mathrm{on}}=150 \mu \mathrm{s}\right)$.

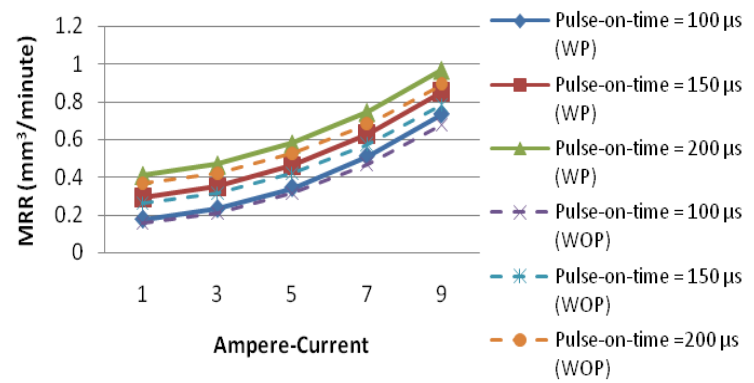

Fig. 12. Impact of ampere-current on MRR for various $\mathrm{T}_{\mathrm{on}}(\mathrm{WS}=600 \mathrm{rpm}, \mathrm{DC}=$ 0.690 )

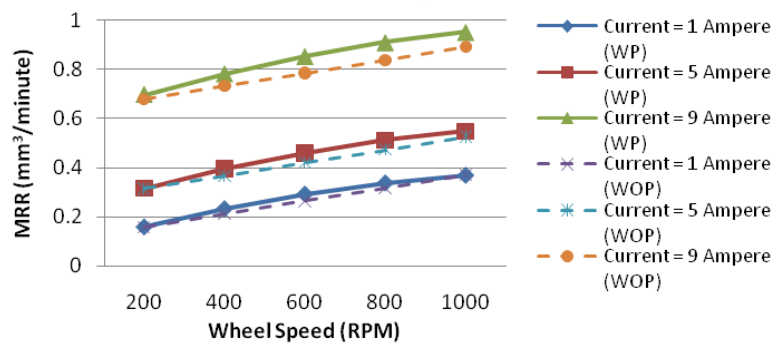

Fig. 14. Impact of WS on MRR for various ampere-current $\left(\mathrm{T}_{\mathrm{on}}=150 \mu \mathrm{s}, \mathrm{DC}=0.690\right)$
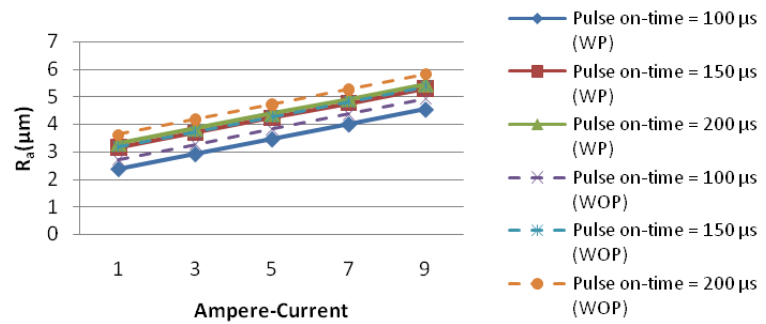

16. Impact of ampere-current on $\mathrm{R}_{\mathrm{a}}$ for various $\mathrm{T}_{\mathrm{on}}(\mathrm{WS}=600 \mathrm{rpm}, \mathrm{DC}=0.690)$. 


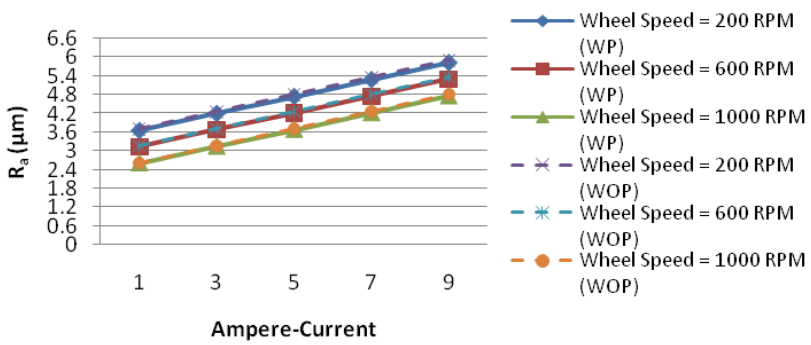

Fig. 17. Impact of ampere-current on $\mathrm{R}_{\mathrm{a}}$ for

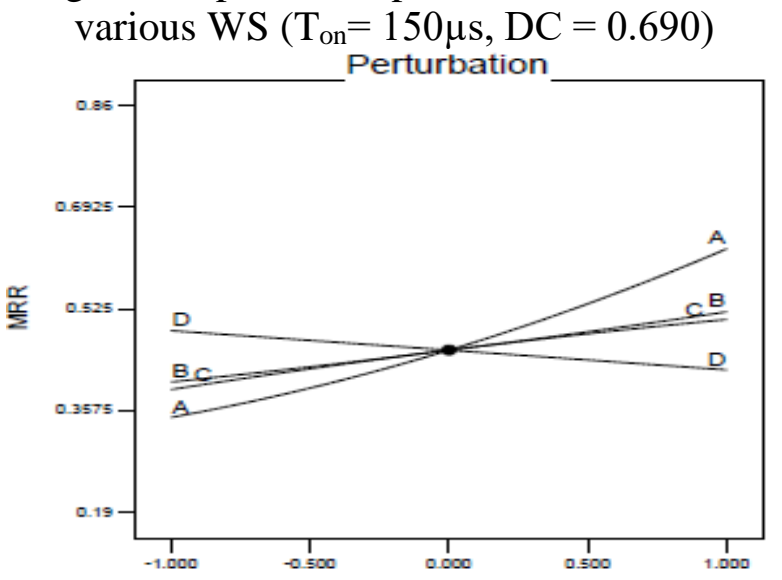

Deviation from Reference Point (Coded Units)

Fig. 19. Perturbation plots for MRR with $\mathrm{Cr}$ powder Perturbation

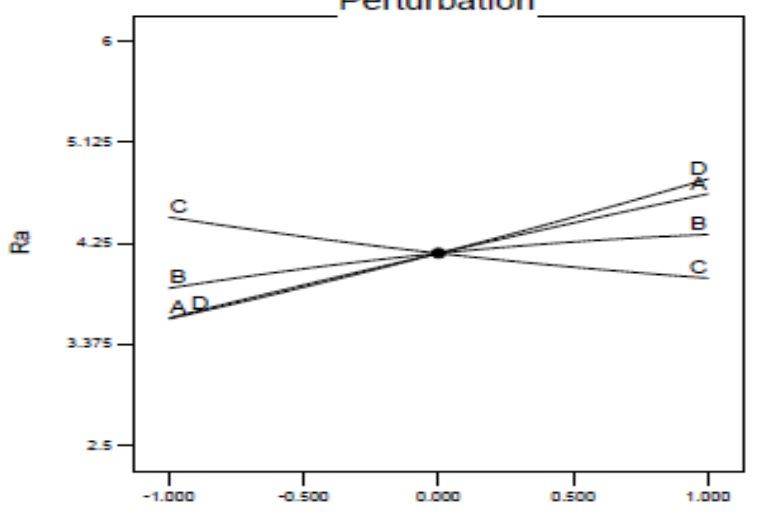

Deviation from Reference Point (Coded Units)

Fig. 21. Perturbation plots for $\mathrm{R}_{\mathrm{a}}$ with $\mathrm{Cr}$ powder.

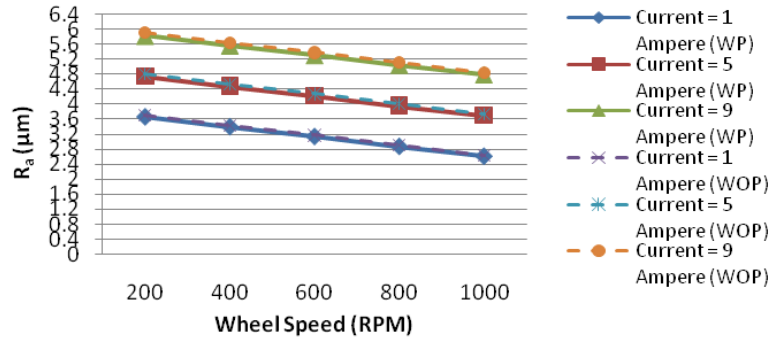

Fig. 18. Impact of $\mathrm{WS}$ on $\mathrm{R}_{\mathrm{a}}$ for various ampere-current $\left(\mathrm{T}_{\mathrm{on}}=150 \mu \mathrm{s}, \mathrm{DC}=0.690\right)$

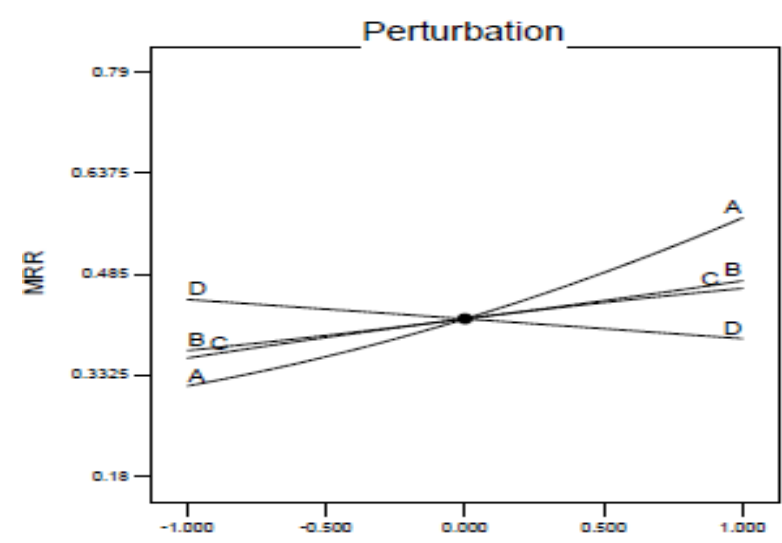

Deviation from Reference Point (Coded Units)

Fig. 20. Perturbation plots for MRR without $\mathrm{Cr}$ powder

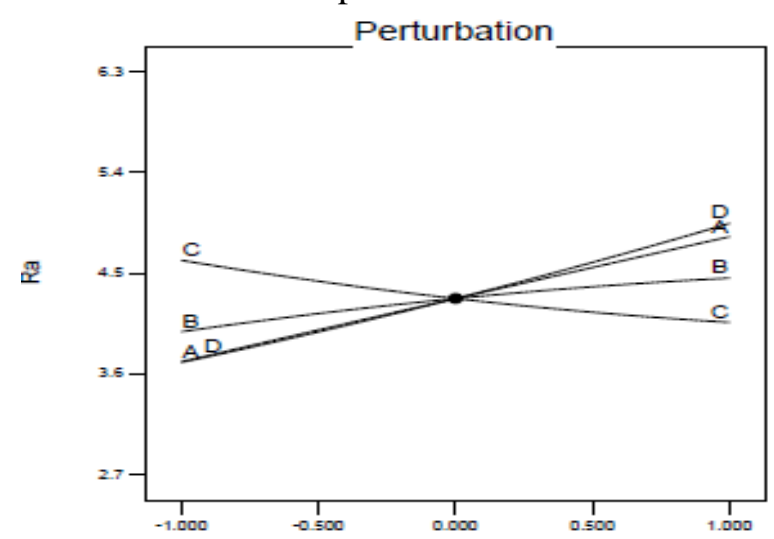

Deviation from Reference Point (Coded Units)

Fig. 22. Perturbation plots for $\mathrm{R}_{\mathrm{a}}$ without $\mathrm{Cr}$ powder

Whereas, with reference to "Figs. from 15 to 18 ", the noticeable rise in surface finish is observed in S-EDDG of Inconel 600 with chromium power blended DF, as compared to the absence of $\mathrm{Cr}$ powder in DF. It occurred on account of the presence of $\mathrm{Cr}$ powder in the electrode gap reformed the plasma channel. The plasma channel is wider and larger and the discharge spark-energy is uniformly dispersed among the $\mathrm{Cr}$ powder particles and consequently responsible for the development of narrower size cavities on the worked surface.

The perturbation plot for MRR with and without $\mathrm{Cr}$ powder mixed condition is displayed in "Figs. 19 and 20" respectively. The sharp-incline for current (A) and DC (D) demonstrates towards high affectability of MRR towards them. Similarly, lines of less steep for WS (C), and $\mathrm{T}_{\text {on }}(\mathrm{B})$ show less affectability of MRR towards them. The MRR is more with chromium powder as compared to without $\mathrm{Cr}$ powder blended DF. 
The perturbation plot for $\mathrm{R}_{\mathrm{a}}$ with and without $\mathrm{Cr}$ powder mixed condition is displayed in "Figs. 21 and 22" respectively. The sharp-incline for current (A) and WS (C) demonstrates towards high affectability of $R_{a}$ towards them. Similarly, lines of less steep for DC (D), and $\mathrm{T}_{\text {on }}(\mathrm{B})$ show less affectability of $\mathrm{R}_{\mathrm{a}}$ towards them. The $\mathrm{R}_{\mathrm{a}}$ is less with $\mathrm{Cr}$ powder as compared to without $\mathrm{Cr}$ powder blended DF.

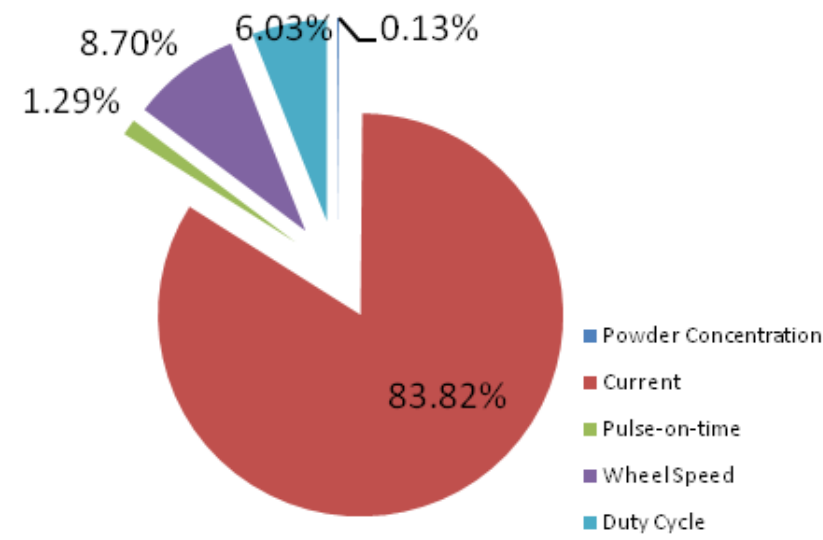

Fig. 23. \% contribution of machining process - factors on WMPI.

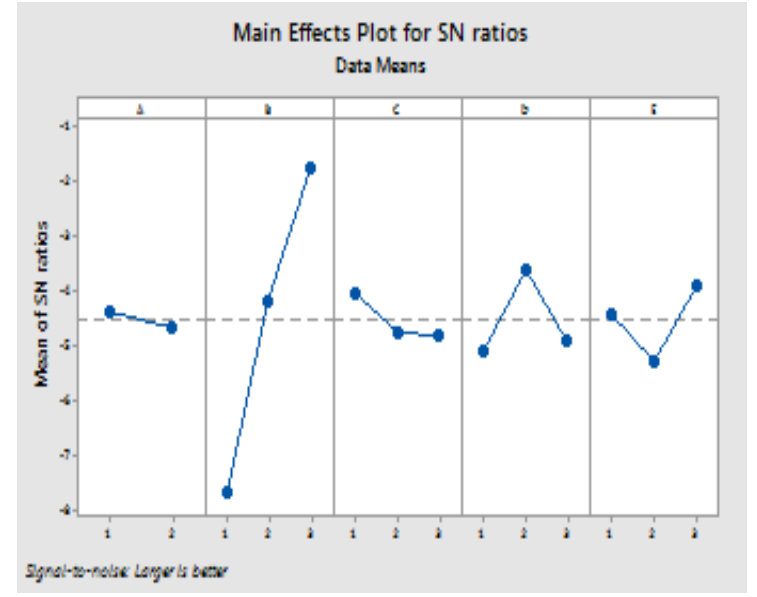

Fig. 24. S/N-ratio plot of WMPI

Table 9 Analysis of outcomes and interpretation of Figs 11 to 18

\begin{tabular}{|c|c|c|c|c|c|c|}
\hline $\begin{array}{l}\text { Figure } \\
\text { No. }\end{array}$ & $\begin{array}{l}\text { Continual- } \\
\text { line/ Dot- } \\
\text { line }\end{array}$ & $\begin{array}{l}\text { Experimental } \\
\text { Condition } \\
\text { (with } \mathrm{Cr} \text { and } \\
\text { absence of } \mathrm{Cr} \\
\text { powder) } \\
\end{array}$ & $\begin{array}{c}\text { Tendency } \\
1 \\
\text { in Figure }\end{array}$ & $\begin{array}{c}\text { Cause for } \\
\text { Tendency } 1 \text { in } \\
\text { Figure }\end{array}$ & $\begin{array}{c}\text { Tendency } \\
2 \\
\text { in Figure }\end{array}$ & $\begin{array}{c}\text { Cause for } \\
\text { Tendency } 2 \text { in } \\
\text { Figure }\end{array}$ \\
\hline \multirow{2}{*}{11} & $\begin{array}{l}\text { Continual- } \\
\text { line }\end{array}$ & $\begin{array}{l}\text { Presence of } \mathrm{Cr} \\
\text { powder }\end{array}$ & \multirow{2}{*}{$\begin{array}{l}\text { MRR } \\
\text { enhances } \\
\text { with the } \\
\text { growth in } \\
\text { ampere } \\
\text { current. }\end{array}$} & \multirow{2}{*}{$\begin{array}{l}\text { The additional } \\
\text { spark } \\
\text { discharge is } \\
\text { produced due } \\
\text { to the growth } \\
\text { in ampere } \\
\text { current. }\end{array}$} & \multirow{2}{*}{$\begin{array}{c}\text { MRR } \\
\text { enhances } \\
\text { with the } \\
\text { decrease in } \\
\text { duty cycle. }\end{array}$} & \multirow{2}{*}{$\begin{array}{l}\text { Pulse off time is } \\
\text { improving } \\
\text { persistently to get the } \\
\text { descending pattern in } \\
\text { the duty-cycle. This } \\
\text { is why adequate } \\
\text { flushing and } \\
\text { deionization time is } \\
\text { accessible for the } \\
\text { dielectric. }\end{array}$} \\
\hline & Dot line & $\begin{array}{l}\text { Absence of } \mathrm{Cr} \\
\text { powder }\end{array}$ & & & & \\
\hline \multirow{2}{*}{12} & $\begin{array}{l}\text { Continual- } \\
\text { line }\end{array}$ & $\begin{array}{l}\text { Presence of } \mathrm{Cr} \\
\text { powder }\end{array}$ & \multirow{2}{*}{ " } & \multirow{2}{*}{$"$} & \multirow{2}{*}{$\begin{array}{l}\text { MRR } \\
\text { enhances } \\
\text { with } \\
\text { the growth } \\
\text { in pulse- } \\
\text { on-time. }\end{array}$} & \multirow{2}{*}{$\begin{array}{l}\text { Pulse-on-time is } \\
\text { growing-up } \\
\text { continuously. This is } \\
\text { why sufficient time is } \\
\text { available for the heat- } \\
\text { conduction. }\end{array}$} \\
\hline & Dot line & $\begin{array}{l}\text { Absence of } \mathrm{Cr} \\
\text { powder }\end{array}$ & & & & \\
\hline \multirow[b]{2}{*}{13} & $\begin{array}{l}\text { Continual- } \\
\text { line }\end{array}$ & $\begin{array}{l}\text { Presence of } \mathrm{Cr} \\
\text { powder }\end{array}$ & \multirow{2}{*}{ " } & \multirow{2}{*}{ ", } & \multirow{2}{*}{$\begin{array}{l}\text { MRR } \\
\text { enhances } \\
\text { with the } \\
\text { rise in } \\
\text { wheel } \\
\text { speed. }\end{array}$} & \multirow{2}{*}{$\begin{array}{c}\text { Additional discharge } \\
\text { energy is dissipated } \\
\text { due to the increase in } \\
\text { wheel speed. It } \\
\text { occurs due to the } \\
\text { current-flow rate in } \\
\text { the grinding area } \\
\text { rises. }\end{array}$} \\
\hline & Dot line & $\begin{array}{l}\text { Absence of } \mathrm{Cr} \\
\text { powder }\end{array}$ & & & & \\
\hline 14 & $\begin{array}{l}\text { Continual- } \\
\text { line }\end{array}$ & $\begin{array}{l}\text { Presence of } \mathrm{Cr} \\
\text { powder }\end{array}$ & $\begin{array}{c}\text { MRR } \\
\text { upgrades }\end{array}$ & $\begin{array}{c}\text { Flushing } \\
\text { enhances and }\end{array}$ & $\begin{array}{c}\text { MRR } \\
\text { enhances }\end{array}$ & $\begin{array}{l}\text { The additional spark } \\
\text { discharge is produced }\end{array}$ \\
\hline
\end{tabular}




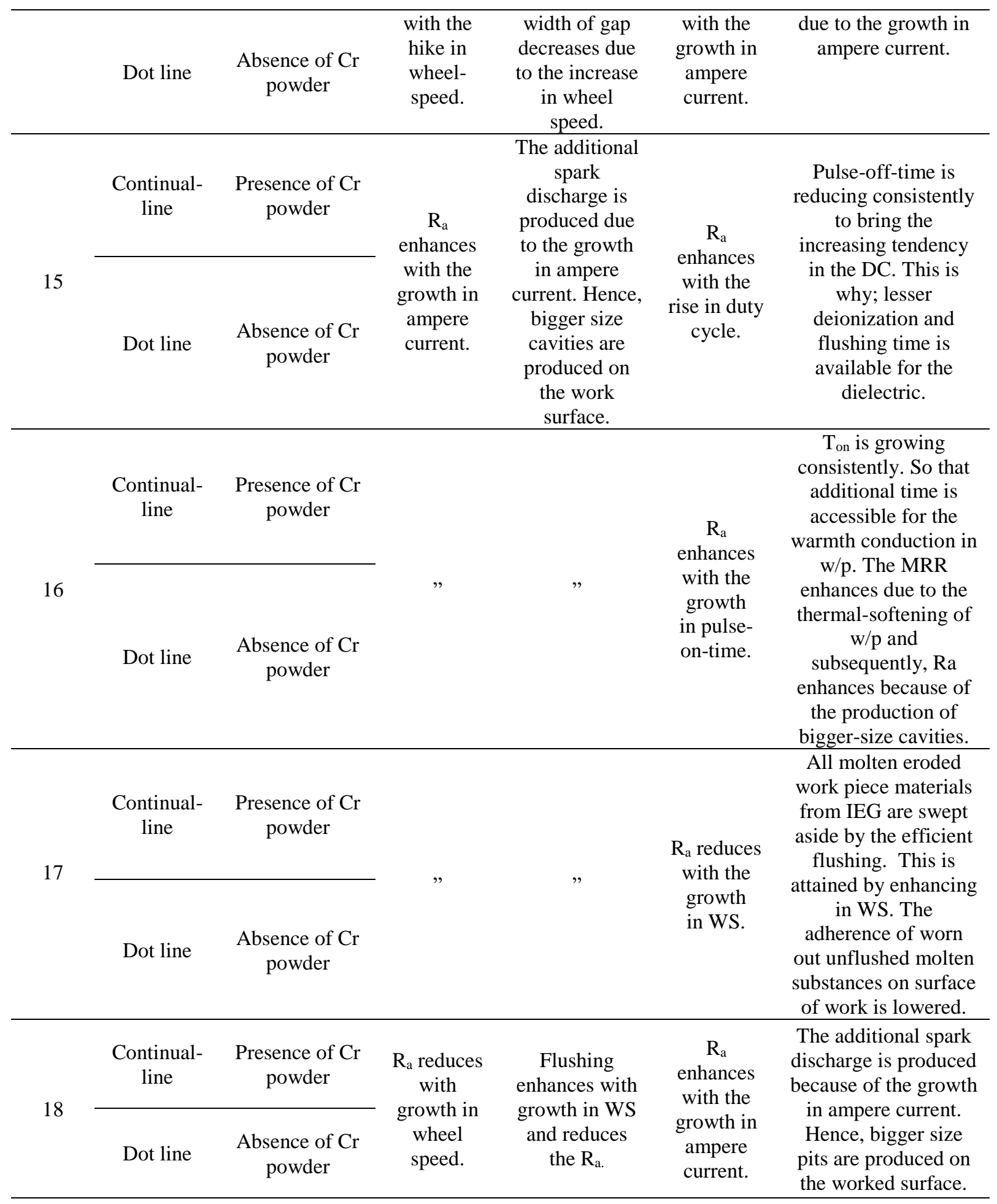

\section{Parametric Optimization with Grey-TM based WPCA approach}

One set of 18 experiments was performed in accordance with $\mathrm{L}_{18} \mathrm{O}-\mathrm{A}$ on $\mathrm{Cr}$ Powder Mixed S-EDDG frame-up with Inconel 600 material. Dependent upon beginning test outcomes and EDM machine confine, the level of process factors was picked as portrayed in Table 10. The proposed methodology for multi response optimization of process factors is described as follows.

The collected values of experimental responses were normalized using the "Eqs. (7), and (8)", to limit the redundancies as well as to limit the dependency among the output-responses. 
The MRR has the higher the better execution a quality is normalized using "Eq. (7)" while the $\mathrm{R}_{\mathrm{a}}$ has the lower is the better execution attributes is normalized using the "Eq. 8". Table 11 depicts the $\mathrm{L}_{18} \mathrm{O}-\mathrm{A}$, process-responses, $\log -\mathrm{S}$, and normalised log-S value.

$$
\begin{aligned}
x_{i}^{*}(t) & =\frac{x_{i}^{(o)}(t)-\min \cdot x_{i}^{(o)}(t)}{\max \cdot x_{i}^{(o)}(t)-\min \cdot x_{i}^{(o)}(t)} \\
x_{i}^{*}(t) & =\frac{\max \cdot x_{i}^{(o)}(t)-x_{i}^{(o)}(t)}{\max \cdot x_{i}^{(o)}(t)-\min \cdot x_{i}^{(o)}(t)}
\end{aligned}
$$

Where, $x_{i}^{(o)}(t)=$ Original-arrangement, $x_{i}^{(*)}(t)=$ Normalized Value, $\min \cdot x_{i}^{(o)}(t)=$ Minimal estimation of $x_{i}^{(o)}(t), \max . x_{i}^{(o)}(t)=$ Extreme estimation of $x_{i}^{(o)}(t), \mathrm{i}=1,2,3, \ldots \mathrm{p} ; \mathrm{t}$ $=1,2 \ldots \mathrm{q} ; \mathrm{p}=$ Entire experiment, and $\mathrm{q}=$ Full observation data.

The deviation sequence $\left[\Delta_{\mathrm{oi}}(\mathrm{t})\right]$ and GR coefficient is determined using the "Eqs. (9), and (10)" respectively. The deviation sequence gives the variation and GR coefficient provides the relational degree among the compatibility and reference sequence.

$$
\begin{gathered}
\Delta_{o i}(t)=\left|x_{o}^{(*)}(t)-x_{i}^{*}(t)\right| \\
\gamma\left(x_{o}^{(*)}(t), x_{i}^{(*)}(t)\right)=\frac{\Delta_{\text {min. }}+\zeta \Delta_{\text {max. }}}{\Delta_{o i}(t)+\zeta \Delta_{\max .}} \\
0<\gamma\left(x_{0}^{*}(t), x_{i}^{*}(t)\right) \leq 1, \Delta_{\text {max. }}=\max _{\forall j \in i} \max _{\forall t}\left|x_{o}^{*}(t)-x_{j}^{*}(t)\right|, \Delta_{\text {min. }}=\min _{\forall j \in i} . \min _{\forall t}\left|x_{o}^{*}(t)-x_{j}^{*}(t)\right|
\end{gathered}
$$

Here,

$$
\begin{aligned}
& x_{o}^{(*)}(t) \quad \text { Reference-Sequence; } \quad \zeta=\quad \zeta \in[0,1] \\
& x_{i}^{*}(t) \quad \text { Comparability-Sequence. }
\end{aligned}
$$

In PCA technique, the $\mathrm{PC}_{1}$ portrays the maximal change in the gathered data and the $\mathrm{PC}_{2}$ depicts the rest of the difference that was left by the $\mathrm{PC}_{1}$ etcetera. Principal components are evaluated using the "Eqs. (11) to (13)".. PC analysis is utilized to clarify the structure of covariance-variance by the linear coalition of the primal factors. Expect that there are p-parts to speak to the framework inconstancy. By utilizing PC Analysis, the framework changeability might be clarified by a less number, $m(m \leq p)$, of the PCs, i.e. $m$ PCs will represent the larger part of difference inside the primal $\mathrm{p}$ factors. For the response-factors, $\mathrm{Z}_{1}$, $\mathrm{Z}_{2} \ldots, \mathrm{Zp}$, there is the accompanying PCs i.e. $Y i(i=1,2,3 \ldots, \mathrm{m})$. These PCs can be expressed by the following "Eqs. (11) to (13)".

$$
\begin{gathered}
Y_{1}=a_{11} Z_{1}+a_{12} Z_{2}+\ldots .+a_{i p} Z_{P} \\
Y_{2}=a_{21} Z_{1}+a_{22} Z_{2}+\ldots .+a_{2 p} Z_{P} \\
Y_{m}=a_{m_{1}} Z_{1}+a_{m_{2}} Z_{2}+\ldots \ldots+a_{m_{p}} Z_{P}
\end{gathered}
$$

where

$$
a_{m 1}^{2}+a_{m 2}^{2}+\cdots+a_{m p}^{2}=1
$$


Table 10. Input factors and its range

\begin{tabular}{ccccc}
\hline Symbol & Control Processes Parameters & Level-1 & Level-2 & Level-3 \\
\hline PC & Cr Powder Concentration (gm/litre) & 1.5 & 3 & - \\
I & Current (Ampere) & 1 & 3 & 5 \\
$\mathrm{~T}_{\text {on }}$ & Pulse-on-time $(\mu s)$ & 50 & 100 & 150 \\
$\mathrm{~S}$ & Wheel Speed (RPM) & 300 & 500 & 700 \\
$\mathrm{DC}$ & Duty Cycle & 0.57 & 0.60 & 0.63 \\
\hline
\end{tabular}

Table 11. $\mathrm{L}_{18} \mathrm{O}-\mathrm{A}$, process-responses, log-S, and normalised log-S value

\begin{tabular}{cccccccccccc}
\hline Exp. & \multicolumn{4}{c}{ Control Factors } & \multicolumn{3}{c}{ Responses } & \multicolumn{2}{c}{ Log-S value } & \multicolumn{2}{c}{ Normalised Log-S value } \\
\cline { 2 - 11 } No. & PC & $\mathrm{I}$ & $\mathrm{T}_{\text {on }}$ & $\mathrm{S}$ & $\mathrm{DC}$ & $\mathrm{MRR}$ & $\mathrm{R}_{\mathrm{a}}$ & $\mathrm{MRR}$ & $\mathrm{R}_{\mathrm{a}}$ & $\mathrm{MRR}$ & $\mathrm{R}_{\mathrm{a}}$ \\
\hline 1 & 1 & 1 & 1 & 1 & 1 & 0.198 & 1.390 & -14.0667 & -2.8603 & 0.455 & 0.199 \\
2 & 1 & 1 & 2 & 2 & 2 & 0.210 & 1.200 & -13.5556 & -1.5836 & 0.539 & 0.125 \\
3 & 1 & 1 & 3 & 3 & 3 & 0.199 & 0.911 & -14.0229 & 0.8096 & 0.462 & -0.014 \\
4 & 1 & 2 & 1 & 1 & 2 & 0.217 & 3.010 & -13.2708 & -9.5713 & 0.586 & 0.590 \\
5 & 1 & 2 & 2 & 2 & 3 & 0.240 & 4.154 & -12.3958 & -12.3693 & 0.730 & 0.752 \\
6 & 1 & 2 & 3 & 3 & 1 & 0.202 & 3.170 & -13.8930 & -10.0212 & 0.483 & 0.616 \\
7 & 1 & 3 & 1 & 2 & 1 & 0.290 & 4.920 & -10.7520 & -13.8393 & 1.000 & 0.838 \\
8 & 1 & 3 & 2 & 3 & 2 & 0.215 & 4.830 & -13.3512 & -13.6789 & 0.573 & 0.829 \\
9 & 1 & 3 & 3 & 1 & 3 & 0.228 & 6.240 & -12.8413 & -15.9037 & 0.656 & 0.958 \\
10 & 2 & 1 & 1 & 3 & 3 & 0.207 & 1.250 & -13.6806 & -1.9382 & 0.518 & 0.146 \\
11 & 2 & 1 & 2 & 1 & 1 & 0.144 & 0.937 & -16.8328 & 0.5652 & 0.000 & 0.000 \\
12 & 2 & 1 & 3 & 2 & 2 & 0.159 & 1.250 & -15.9721 & -1.9382 & 0.142 & 0.146 \\
13 & 2 & 2 & 1 & 2 & 3 & 0.240 & 5.230 & -12.3958 & -14.3700 & 0.730 & 0.869 \\
14 & 2 & 2 & 2 & 3 & 1 & 0.196 & 3.630 & -14.1549 & -11.1981 & 0.440 & 0.684 \\
15 & 2 & 2 & 3 & 1 & 2 & 0.187 & 2.070 & -14.5632 & -6.3194 & 0.373 & 0.400 \\
16 & 2 & 3 & 1 & 3 & 2 & 0.206 & 5.110 & -13.7227 & -14.1684 & 0.511 & 0.857 \\
17 & 2 & 3 & 2 & 1 & 3 & 0.183 & 5.880 & -14.7510 & -15.3875 & 0.342 & 0.928 \\
18 & 2 & 3 & 3 & 2 & 1 & 0.242 & 6.780 & -12.3237 & -16.6246 & 0.742 & 1.000 \\
\hline
\end{tabular}

$Y_{1}$ is known as the first important PC, $Y_{2}$ is known as the second key PC and $\mathrm{a}_{\mathrm{m} 1}, \mathrm{a}_{\mathrm{m} 2} \ldots, \mathrm{a}_{\mathrm{mp}}$ are the components of the eigen-vector comparing to the $\mathrm{m}^{\text {th }}$ biggest eigen-value. The $\mathrm{m}^{\text {th }}$ segment-coefficient is the parts of the eigen-vector matching to the $\mathrm{m}^{\text {th }}$ greatest eigen-values. Nonetheless, there are as yet two evident inadequacies in the PCA technique. To start with, when in excess of one key segment (i.e. PC) is chosen whose eigen-value is more prominent than 1, the required exchange-off for a practical result is obscure; and second, the MPI can't supplant the multi-response result when the picked PC can only be clarified by aggregatevariation. WPCA technique is utilized here to defeat the inadequacies of multi-response issue in the PCA approach. The WPCA technique utilizes the clarified variation as the weight to join all PCs with the end goal to frame a WMPI. WPCA is a viable method to depict the slight number of segments which is accountable for the main sources of variance in a setarrangement of related quality-properties. WPCA has been conducted on GRC of every quality-characteristic and determine the Eigen-value, and Eigen-vector from concurrence matrix created by GRC. Minitab software is used for WPC analysis. The WMP index can be utilized to decide the optimal setting of process parameters. The greater the estimation of WMPI suggests the better the product-quality. WMPI is computed utilizing the "Eq. (14)".

$$
W M P I=\sum_{i=1}^{m} W_{m} P C_{m}
$$

where, $\mathrm{W}_{\mathrm{m}}$ is the weight of $\mathrm{i}^{\text {th }} \mathrm{PC}$ 's. Table 12 showed the deviation-sequence, GRC, WMPI, Log-S value of WMPI. The eigen-values and eigen-vector is displayed in Table 13. 
Table 12. Deviation-sequence, GRC, WMPI, and Log-S value of WMPI

\begin{tabular}{ccccccc}
\hline \multirow{2}{*}{ Exp. No. } & \multicolumn{2}{c}{ Deviation Sequence } & \multicolumn{2}{c}{ GRC } & \multirow{2}{*}{ WMPI } & \multirow{2}{*}{ Log-S value of WMPI } \\
\cline { 2 - 5 } & MRR & $\mathrm{R}_{\mathrm{a}}$ & $\mathrm{MRR}$ & $\mathrm{R}_{\mathrm{a}}$ & & \\
\hline 1 & 0.545 & 0.801 & 0.478 & 0.384 & 0.444 & -7.060 \\
2 & 0.461 & 0.875 & 0.520 & 0.364 & 0.444 & -7.053 \\
3 & 0.538 & 1.014 & 0.482 & 0.330 & 0.406 & -7.819 \\
4 & 0.414 & 0.410 & 0.547 & 0.549 & 0.585 & -4.661 \\
5 & 0.270 & 0.248 & 0.649 & 0.669 & 0.706 & -3.024 \\
6 & 0.517 & 0.384 & 0.492 & 0.566 & 0.576 & -4.784 \\
7 & 0.000 & 0.162 & 1.000 & 0.755 & 0.893 & -0.982 \\
8 & 0.427 & 0.171 & 0.539 & 0.745 & 0.720 & -2.851 \\
9 & 0.344 & 0.042 & 0.593 & 0.923 & 0.865 & -1.258 \\
10 & 0.482 & 0.854 & 0.509 & 0.369 & 0.444 & -7.053 \\
11 & 1.000 & 1.000 & 0.333 & 0.333 & 0.355 & -8.986 \\
12 & 0.858 & 0.854 & 0.368 & 0.369 & 0.393 & -8.108 \\
13 & 0.270 & 0.131 & 0.649 & 0.792 & 0.793 & -2.012 \\
14 & 0.560 & 0.316 & 0.472 & 0.613 & 0.603 & -4.396 \\
15 & 0.627 & 0.600 & 0.444 & 0.455 & 0.481 & -6.359 \\
16 & 0.489 & 0.143 & 0.506 & 0.778 & 0.732 & -2.716 \\
17 & 0.658 & 0.072 & 0.432 & 0.874 & 0.773 & -2.235 \\
18 & 0.258 & 0.000 & 0.659 & 1.000 & 0.944 & -0.503 \\
\hline
\end{tabular}

Table 13. Eigen-values and Eigen-vector

\begin{tabular}{ccc}
\hline & $\mathrm{PC}_{1}$ & $\mathrm{PC}_{2}$ \\
\hline Eigen value & 1.5070 & 0.4930 \\
Eigen vector & {$[0.707,0.707]$} & {$[-0.707,0.707]$} \\
Proportion & 0.754 & 0.246 \\
Cumulative & 0.754 & 1.0
\end{tabular}

Table 14. Response and ANOVA-table for WMPI.

\begin{tabular}{|c|c|c|c|c|c|c|c|c|c|c|}
\hline \multicolumn{4}{|c|}{ Response-table } & \multirow[b]{2}{*}{ Symbol } & \multicolumn{6}{|c|}{ ANOVA-table } \\
\hline $\begin{array}{c}\text { Level- } \\
1\end{array}$ & $\begin{array}{l}\text { Level- } \\
2\end{array}$ & $\begin{array}{c}\text { Level- } \\
3\end{array}$ & $\begin{array}{l}\text { Max- } \\
\text { Min }\end{array}$ & & DF & SS & MS & $\mathrm{F}$ & $\mathrm{P}$ & $\begin{array}{c}\mathrm{C} \\
(\%)\end{array}$ \\
\hline$-4.388^{p}$ & $\begin{array}{l}-4.708 \\
\end{array}$ & & 0.319 & $\mathrm{PC}$ & 1 & 0.000824 & 0.000824 & 0.49 & 0.506 & 0.13 \\
\hline-7.680 & -4.206 & $-1.758^{p}$ & 5.92 & I & 2 & 0.496380 & 0.248190 & 146.37 & 0.000 & 83.82 \\
\hline$-4.081^{p}$ & -4.758 & -4.805 & 0.725 & $\mathrm{~T}_{\mathrm{ON}}$ & 2 & 0.007650 & 0.003825 & 2.26 & 0.167 & 1.29 \\
\hline-5.093 & $-3.614^{\mathrm{p}}$ & -4.937 & 1.479 & $S$ & 2 & 0.051567 & 0.025784 & 15.21 & 0.002 & 8.70 \\
\hline-4.452 & -5.291 & $-3.900^{\mathrm{p}}$ & 1.391 & DC & 2 & 0.035740 & 0.017870 & 10.54 & 0.006 & 6.03 \\
\hline & & & & Error & 8 & 0.013565 & 0.001696 & & & \\
\hline & & & & Total & 17 & 0.605727 & & & & \\
\hline
\end{tabular}

\section{Discussion}

ANOVA examination was conducted on WMPI. The result of ANOVA and the impact of several machining factors on the WMPI are listed in Table 14. The \% contribution of machining factors is depicted in "Fig. 23". "Fig. 24" delineated the S/N-ratio plot of WMPI. The optimal setting of several machining factors determined through GRA-TM based WPCA approach in Cr powder mixed S-EDDG of Inconel 600, is PC at first level, I at third level, $\mathrm{T}_{\text {on }}$ at first level, S at second level, and DC at third level. The current, wheel speed, and duty cycle are the most significant factors that influence process performance characteristic.

\subsection{Confirmation test}

The estimated $\hat{\alpha}$ grade is computed utilizing the "Eq. (15)". 


$$
\hat{\alpha}=\alpha_{m}+\sum_{i=1}^{n}\left(\bar{\alpha}_{i}-\alpha_{m}\right)
$$

Where, $\alpha_{m}=$ average grade, $\bar{\alpha}_{i}=$ optimal average grade, and ' $\mathrm{n}$ ' is the total main-process factors which influence the multi-output performance characteristics. To assure the improvement in quality-performance, an affirmation test is carried out. The result of this test is shown in Table 15.

Table 15. Result of confirmation test

\begin{tabular}{|c|c|c|c|}
\hline \multirow{3}{*}{ Factor-Level } & \multirow{2}{*}{ Initial Process-Parameters } & \multicolumn{2}{|c|}{ Optimal Process-parameter } \\
\hline & & Prediction & Experiment \\
\hline & $P C_{1} I_{1} T_{m} S_{1} D_{1}$ & $P C_{1} I_{3} T_{o n_{1}} S_{2} D_{3}$ & $P C_{1} I_{3} T_{o_{1}} S_{2} D_{3}$ \\
\hline $\operatorname{MRR}\left(\mathrm{mm}^{3} / \mathrm{min}\right)$ & 0.198 & - & 0.276 \\
\hline $\mathrm{R}_{\mathrm{a}}(\mu m)$ & 1.390 & - & 5.010 \\
\hline WMPI & 0.444 & 0.97 & 0.858 \\
\hline
\end{tabular}

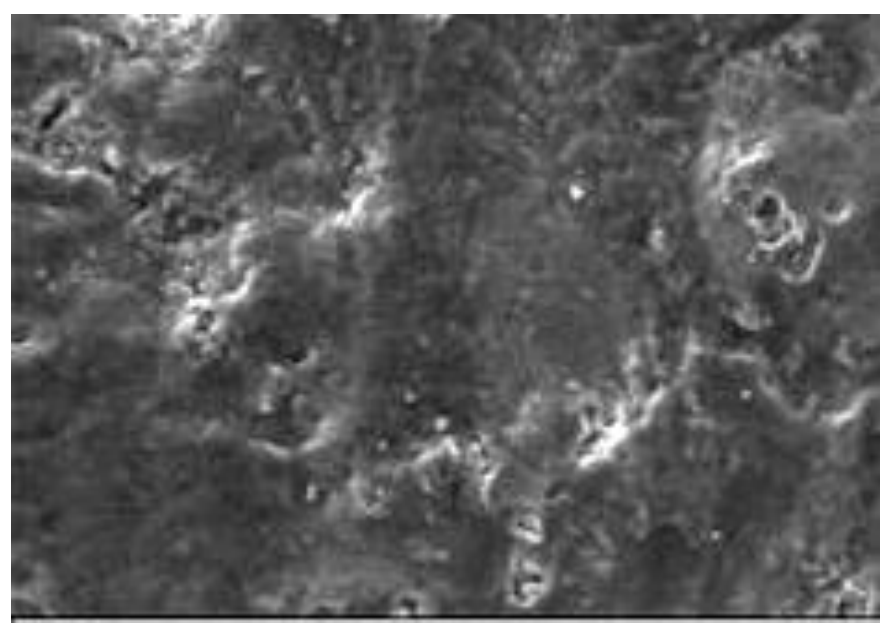

a)

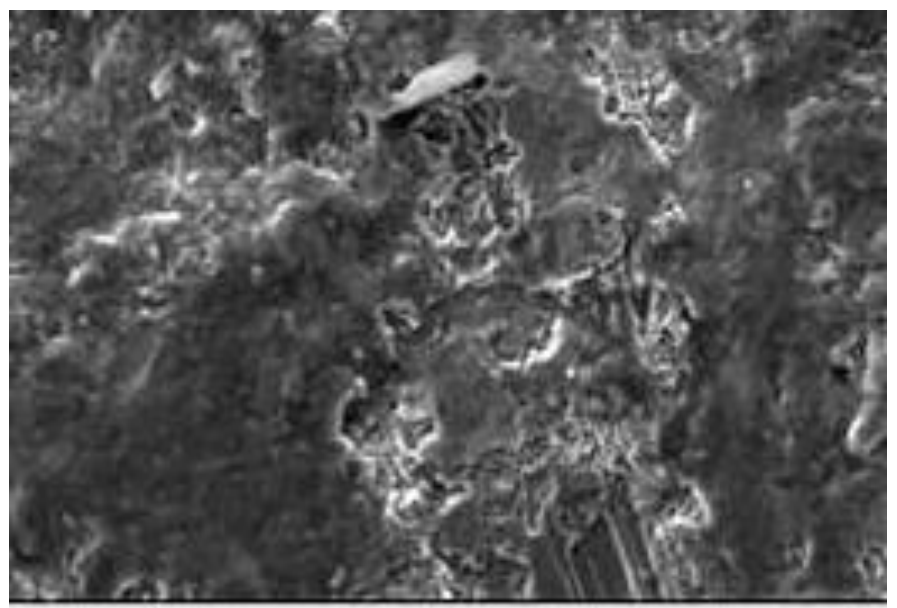

b)

Fig. 25. Effect of presence of chromium and absence of chromium powder in dielectric fluid on the surface generation of machined surfaces of Inconel 600 through S-EDDG process at optimum condition a) S-EDDG produced surface with $\mathrm{Cr}$ powder mixed dielectric fluid, b) SEDDG produced surface without powder mixed dielectric fluid $\left(I=5 \mathrm{~A}, T_{o n}=50 \mu \mathrm{s}, D C=\right.$ 0.63 and $W S=500$ RPM) 


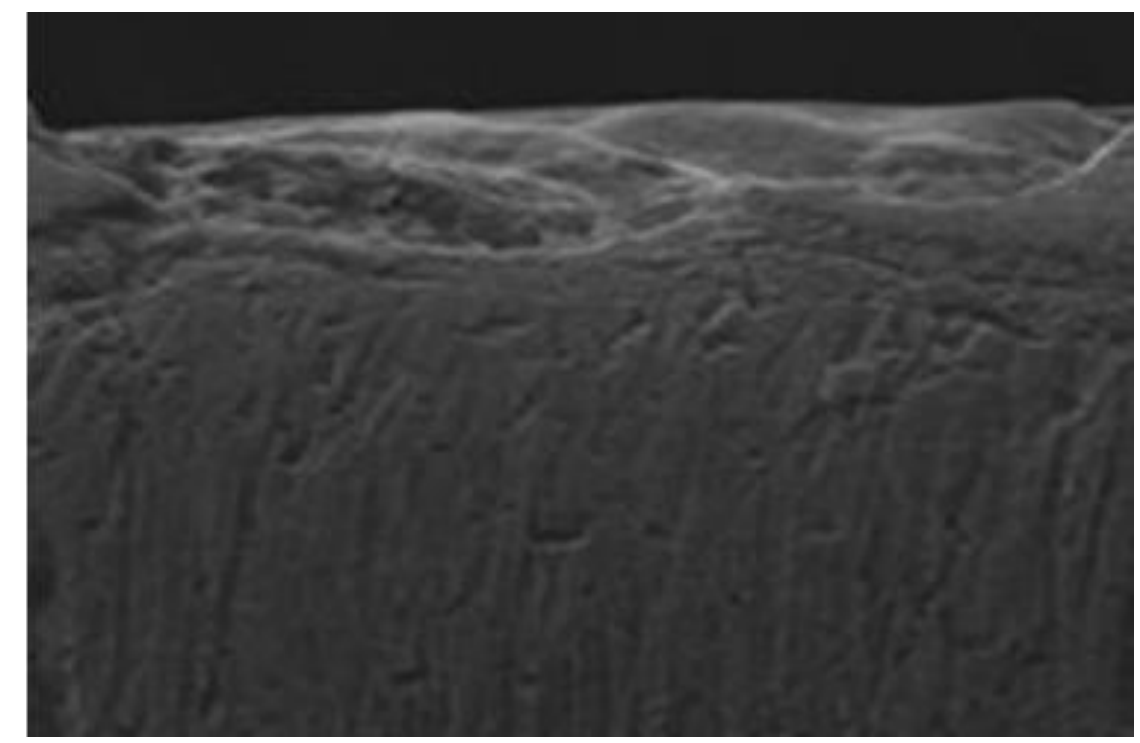

a)

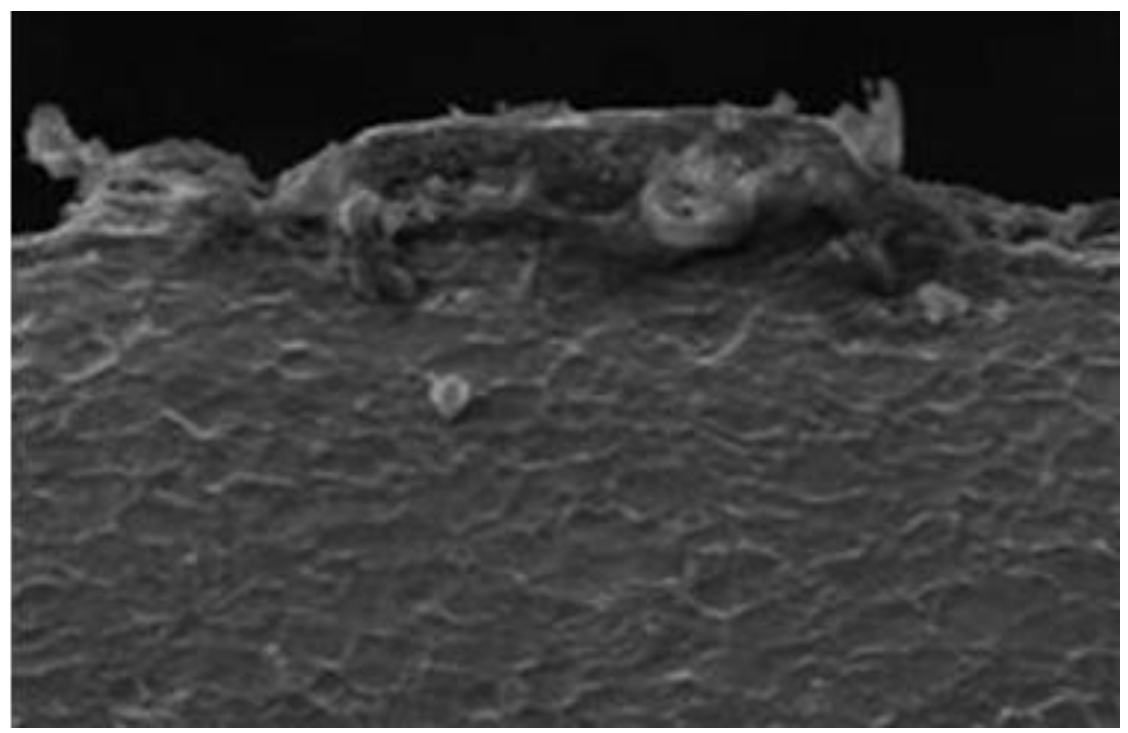

b)

Fig. 26. Effect of presence of chromium and absence of chromium powder in dielectric fluid on the WRLT of machined surface of Inconel 600 through S-EDDG process at optimum condition a) With $\mathrm{Cr}$ powder mixed dielectric fluid; $\mathrm{t}=47 \mu \mathrm{m} ; \mathrm{b})$ Without $\mathrm{Cr}$ powder mixed dielectric fluid; $\mathrm{t}=32 \mu \mathrm{m} ;\left(I=5 \mathrm{~A}, T_{\text {on }}=50 \mu \mathrm{s}, D C=0.63\right.$ and $\left.W S=500 \mathrm{RPM}\right)$

\section{Analysis of surface generation and WRLT in S-EDDG of Inconel 600 with chromium and absence of $\mathrm{Cr}$ powder blended DF at optimum condition}

The SEM investigation has been conducted on the S-EDDG produced surfaces with chromium and absence of $\mathrm{Cr}$ powder blended DF at the optimum condition. In the "Figs. 25 (a) and (b)", it was seen that the detectable ascent in the surface-finish of work-material with $\mathrm{Cr}$ powder as compared to the absence of $\mathrm{Cr}$ powder blended in DF. The presence of $\mathrm{Cr}$ powder in between the electrodes reformed the plasma channel. The produced spark energy is evenly shared among the $\mathrm{Cr}$ powder particles and thus accountable for the creation of narrower size pits on the worked surface.

If the melted material from surface isn't flushed rapidly, it will re-set on account of the cooling impact of the DF and stick to the created machined-surface. This stuck layer is known as the recast-white-layer. In the "Fig. 26 (a) and (b)", it is seen that wrl thickness is more with 
chromium as compared to absence of chromium powder blended DF. It is happened due to the presence of $\mathrm{Cr}$ powder particles in DF increase the gap spacing among the electrodes and consequently responsible for ineffective flushing condition in IEG as compared to the absence of $\mathrm{Cr}$ powder particles in DF.

\section{CONCLUSIONS}

The following conclusions could be drawn based on the examination of experimental results, understanding of "Figs. 3 to 22, 25, and 26", integrated optimization approach, and SE-M pictures examinations:

1. MRR, surface-finish, and white recast layer thickness is more in chromium powder mixed dielectric fluid in contrast to dielectric fluid without it, during S-EDDG of Inconel 600.

2. The maximum MRR is attained when current, $T_{o n}$, and wheel-speed are at top levels. In a similar way, the maximum MRR is attained when DC is at the minimal level.

3. The minimal $R_{a}$ is attained when, current, $T_{o n}, D C$ are at the minimal levels. In a similar way, the maximum $R_{a}$ is attained when WS is at the minimal level.

4. Surface craters on the machined surface are narrower and smaller due to presence of chromium powder in contrast to DF without it, during S-EDDG of Inconel 600.

5. It is seen through ANOVA outcomes that the percentage contribution of several process variables on the process performance characteristics is powder concentration $(0.13 \%)$; current $(83.82 \%)$; pulse on time $(1.29 \%)$; wheel speed $(8.70 \%)$; and duty cycle $(6.03 \%)$. The current, wheel speed, and duty cycle are the significant variables which influence the process performance.

6. The Weighted Multiple Performance Index has been enhanced by 0.414 .

\section{REFERENCES}

[1] Aggarwal, V., Khangura, S. S., Garg, R. K. "Parametric modeling and optimization for wire electrical discharge machining of Inconel 718 using response surface methodology", International Journal of Advanced Manufacturing Technology 79 (1-4), pp. 31 - 47, 2015. DOI: http: 10.1007/s00170-015-6797-8

[2] Shaw, M.C, Nakayama, K. "Machining high strength materials", CIRP Annal 15, pp. 45 - 59, 1967. https://www.cirp.net/component/cirppubli/?task=searchpublic\&year=1966

[3] Luo, Y. F. "The dependence of inter space discharge transitivity upon the gap debris in precision electro discharge machining", Journal of Materials Processing Technology 68, pp. 121 - 131, 1997. DOI: 10.1016/S0924-0136(96)00019-2

[4] Ho, K. H., Newman, S. T. "State of the art electrical discharge machining (EDM)", International Journal of Machine Tools \& Manufacture 43, pp. 1287 - 1300, 2003. DOI: 10.1016/S0890-6955(03)00162-7

[5] Lee, H. T., Tai, T. Y. "Relationship between EDM parameters and surface crack formation", Journal of Materials Processing Technology 142, pp. 676 - 683, 2003. DOI: 10.1016/S0924-0136(03)00688-5

[6] Kao, J. Y., Tsao, C. C., Wang, S. S., Hsu, C. Y. "Optimization of the EDM parameters on machining Ti-6Al-4V with multiple quality characteristics", International Journal of Advanced Manufacturing Technology 47, pp. 395 - 402, 2010. DOI: 10.1007/s00170009-2208-3. 
[7] Tzeng, Y. F., Lee, C. Y. "Effects of Powder Characteristics on Electro discharge Machining Efficiency", International Journal of Advanced Manufacturing Technology 17, pp. 586 - 592, 2001. DOI: $10.1007 /$ s001700170142

[8] George, P. M., Raghunath, B. K., Manocha, L. M., Warrier, A. M. "EDM machining of carbon-carbon composite - a Taguchi approach", Journal of Materials Processing Technology 145, pp. 66 - 71, 2004. DOI: 10.1016/S0924-0136(03)00863-X

[9] Modi, M., Jha, S. "Modelling and Analysis of Powder Mixed Electric Discharge Machining”, International Journal of Mechanical Engineering 2, pp. 219 - 223, 2009.

[10] Singh, G. K., Yadava, V, Kumar, R. "Diamond Face Grinding of WC-Co Composite with Spark Assistance: Experimental Study and Parameter Optimization", International Journal of Precision Engineering and Manufacturing 11 (4), pp. 509 - 518, 2010. DOI: $10.1007 / \mathrm{s} 12541-010-0059-3$

[11] Gauri, S. K., Chakraborty, S. "A study on the performance of some multi-response optimisation methods for WEDM processes", International Journal of Advanced Manufacturing Technology 49, pp. 155 - 166, 2010. DOI: 10.1007/s00170-009-2391-2

[12] Lin, J. L., Lin, C. L. "The use of grey-fuzzy logic for the optimization of the manufacturing process", Journal of Materials Processing Technology 160, pp. 9 - 14, 2005. DOI: $10.1016 /$ j.jmatprotec.2003.11.040

[13] Modi, M., Agarwal, G. "Powder-Mixed Electro-Discharge Diamond Surface Grinding Process: Modelling, Comparative Analysis and Multi-Output Optimization Using Weighted Principal Components Analysis", SV-JME 59, pp. 735 - 747, 2013. DOI: 10.5545/sv-jme.2013.1146

[14] Modi, M., Agarwal, G. "Optimization of Electro-Discharge Diamond Surface Grinding Process Parameters with Multiple Performance Characteristics of Ti-6Al-4V using Grey-Taguchi Approach", Advanced Materials Research 622, pp. 14 - 18, 2013. DOI: 10.4028/www.scientific.net/AMR.622-623.14

[15] Chen, S. L., Yan, B. H., Huang, F. Y. "Influence of kerosene and distilled water as dielectrics on the electric discharge machining characteristics of Ti-6A1-4V",Journal of Materials Processing Technology 87, pp. 107 - 111, 1999. DOI: 10.1016/S09240136(98)00340-9

[16] Liao, H. C. "Multi-response optimization using weighted principal component", International Journal of Advanced Manufacturing Technology 27, pp.720 - 725, 2006. DOI: $10.1007 / \mathrm{s} 00170-004-2248-7$

[17] Kumar, S., Singh, R., Batish, A., Singh T. P. "Modeling the tool wear rate in powder mixed electro-discharge machining of titanium alloys using dimensional analysis of cryogenically treated electrodes and workpiece", Journal of Processing Mechanical Engineering, 231 (2), pp. 271 - 282, 2017. DOI: 10.1177\%2F0954408915593875

[18] Ramesh, S., Jenarthanan, M. P., Bhuvanesh Kanna, A. S. "Experimental investigation of powder-mixed electric discharge machining of AISI P20 steel using different powders and tool materials", Multidiscipline Modeling in Materials and Structures 14 (11), 2017. DOI: 10.1108/MMMS-04-2017-0025

[19] Modi, M., Agarwal, G. "Design, Development \& Experimental Investigation of ElectroDischarge Diamond Surface Grinding of Ti-6Al-4V", Advanced Materials Research 418, pp. 1478 - 1481, 2011. DOI: 10.4028/www.scientific.net/AMR.418-420.1478 
[20] Modi, M., Agarwal, G. "Influence of Dielectric Jet flushing during Electro Discharge Diamond Surface Grinding process", Advanced Materials Research 652, pp. 2187 2190, 2013. DOI: 10.4028/www.scientific.net/AMR.652-654.2187

[21] Kumar, S., Dhingra, A. K., kumar, S. "Parametric optimization of powder mixed electrical discharge machining for nickel based super alloy inconel-800 using response surface methodology", Mechanics of Advanced Materials and Modern Processes, Vol. 3:7, 2017, DOI: https://doi.org/10.1186/s40759-017-0022-4

[22] Modi, M., Agarwal, G., Patil, V., Khare, A., Shukla, S., Shankhla, A. "Modeling and analysis of turning process on lathe machine By Taguchi and ANOVA approach", International Journal of Scientific \& Technology Research 8 (10), pp. 1466 - 1470, 2019. http://www.ijstr.org/final-print/oct2019/Modeling-And-Analysis-Of-TurningProcess-On-Lathe-Machine-By-Taguchi-And-Anova-Approach.pdf

[23] Modi, M., Agarwal, G., Patil, V., Bhatia, U., Pancholi, R. "Parametric Optimization in Drilling of $\mathrm{Al}-\mathrm{SiC}$ Composite Using Taguchi Method", International Journal of Scientific \& Technology Research 8 (9), pp. 2019 - 22, 2019. http://www.ijstr.org/finalprint/sep2019/Parametric-Optimization-In-Drilling-Of-Alsic-Composite-UsingTaguchi-Method.pdf

[24] Chander, P., Kansal, H.K., Pabla, B. S., Puri, S. "Experimental Investigations in Powder Mixed Electric Discharge Machining of Ti-35Nb-7Ta-5Zr $\beta$ - Titanium Alloy", Materials and Manufacturing Processes 32 (3), pp. $1-13,2016$. DOI: 10.1080/10426914.2016.1198018

[25] Razak, M. A., Rani, A.M.A., Saad, N. M., Littlefair, G., Aliyu, A. A., "Controlling corrosion rate of Magnesium alloy using powder mixed electrical discharge machining", IOP Conf. Series: Materials Science and Engineering 344, pp. 1 - 10, 2018. DOI: $10.1088 / 1757-899 X / 344 / 1 / 012010$

[26] Modi, M., Agarwal, G. "Effect of aluminium and chromium powder mixed dielectric fluid on electrical discharge machining effectiveness", Advances in Production Engineering \& Management Journal 14 (3), pp. 323 - 332, 2019. DOI: 10.14743/apem2019.3.330

[27] Modi, M., Agarwal, G. "Integrated statistical methodology for optimizing the machining parameters in SIC powder mixed - EDDSG process to machine TI6AL4V", Materiali in tehnologije / Materials and technology Journal 53 (3), pp. 357 - 366, 2019. DOI: $10.17222 / \mathrm{mit} .2018 .194$

[28] De, D., Nandi, T., Bandyopadhyay, A. "Parametric study for wire cut electrical discharge machining of sintered titanium", Strojnícky časopis - Journal of Mechanical Engineering 69 (1), pp. 17 - 38, 2019. DOI: 10.2478/scjme-2019-0002

[29] Raturi, H. P., Prasad, L., Pokhriyal, M., Tirth, V. "An estimating the effect of process parameters on metal removal rate and surface roughness in WEDM of composite AL6063/SIC/AL $\mathrm{O}_{3}$ by Taguchi Method", Strojnícky časopis - Journal of Mechanical Engineering 67 (2), pp. 25 - 36, 2017. DOI: 10.1515/scjme-2017-0015

[30] Yadav, S. U., Yadav, V. "Modelling and optimisation of process parameters of electrical discharge diamond drilling of nimonic alloy - an aerospace material", International Journal of Industrial and Systems Engineering (IJISE) 29 (4), pp. 507 532, 2018. DOI: 10.1504/IJISE.2018.094270 
[31] Koing, W., Cronjager, L., Spur, G., Tonshoff, H. K., Vigneau, M., Zdeblick, W.J., "Machining of new materials", annals of CIRP 39 (2), pp. 673 - 681, 1990. DOI: 10.1016/s0007-8506(07)63004-2

[32] Jain V. K. “Advanced Machining Processes", Allied Publishers Pvt. Ltd., New Delhi, India, 2002.

[33] Design Expert Software, Version 8.0.7.1, User Guide, "Technical manual", Stat-Ease Inc., Minneapolis, MN, 2010.

[34] Montgomery, D. C. "Design, and analysis of experiments", Wiley, New York, 2009.

\begin{tabular}{|c|c|}
\hline Abbreviations & \\
\hline ANOVA & Analysis of variance \\
\hline S-EDDG & Electro Discharge Diamond Surface Grinding \\
\hline EDDG & Electro Discharge Diamond Grinding \\
\hline PMS-EDDG & Powder Mixed Surface Electro Discharge Diamond Grinding \\
\hline DA & Dimensional Analysis \\
\hline PMED-M & Powder Mixed ED-Machining \\
\hline PCA & Principal Component Analysis \\
\hline C-C-R-D & Central Composite Rotary Design \\
\hline $\mathrm{CV}$ & Coefficient of Variation \\
\hline PBED-M & Powder Blended ED-Machining \\
\hline EDM & Electrical Discharge Machining \\
\hline H-M-P & Hybrid Machining Process \\
\hline RSM & Response Surface Methodology \\
\hline $\mathrm{DC}$ & Duty Cycle (\%) \\
\hline DF & Dielectric Fluid \\
\hline I & Ampere-Current (Ampere) \\
\hline MRR & Rate of Material Removal $\left(\mathrm{mm}^{3} /\right.$ minute $)$ \\
\hline SR & Surface Roughness $(\mu \mathrm{m})$ \\
\hline RPM & Revolution per minute \\
\hline WS & Wheel Speed (RPM) \\
\hline $\mathrm{T}_{\text {on }}$ & Pulse-on-time $(\mu \mathrm{s})$ \\
\hline $\mathrm{T}_{\text {off }}$ & Off-time of pulse \\
\hline $\mathrm{T}$ & Time in minute \\
\hline $\mathrm{P}$ & Density of work-piece material $\left(\mathrm{gram} / \mathrm{cm}^{3}\right)$ \\
\hline $\mathrm{Ra}$ & Average Surface Roughness $(\mu \mathrm{m})$ \\
\hline WMPI & Weighted Multiple Performance Index \\
\hline WPCA & Weighted Principal Component Analysis \\
\hline IEG & Inter Electrode Gap \\
\hline $\mathrm{Cr}$ & Chromium \\
\hline GRA & Grey Relational Analysis \\
\hline $\mathrm{TM}$ & Taguchi Method \\
\hline $\mathrm{N} \%$ Probability & Normal Percentage Probability \\
\hline $\mathrm{PC} / \mathrm{PCs}$ & Principal Component/Principal Components \\
\hline
\end{tabular}

Volume 69, No. 4, (2019) @ @2019 SjF STU Bratislava 
GRC

WRLT

SEM

WEDM

S-DG

ED-M/ED-Machining

EDDSG

GRA-PCA

MMCs

MMMCs

$\mathrm{O}-\mathrm{A}$
Grey Relational Coefficients

White Recast Layer Thickness

Scanning Electron Microscopy

Wire EDM

Surface Diamond Grinding

Electrical Discharge Machining

Electrical Discharge Diamond Surface Grindimg

Grey Relational Analysis-Principal Component Analysis

Metal Matrix Composites

Hybrid Metal Matrix Composites

Orthogonal Array 